\title{
THE ISLAMIC PROHIBITION OF ADOPTION AS LIMITATION \\ OF THE RIGHT TO RESPECT FOR FAMILY LIFE \\ (ARTICLE 8 ECHR) - REVISITING ECTHR HARROUDJ \\ $V$ FRANCE, NO 43631/09, 4 OCTOBER 2012
}

\author{
L'INTERDICTION ISLAMIQUE DE L'ADOPTION EN TANT QUE \\ LIMITATION DU DROIT AU RESPECT DE LA VIE FAMILIALE \\ (ARTICLE 8 CONVENTION EDH) - REVISITER COUR \\ EDH HARROUDJ C FRANCE, NO 43631/09, 4 OCTOBRE 2012
}

\author{
Nikos Koumoutzis \\ Associate Professor at the Law School \\ of the University of Nicosia, Cyprus
}

Recibido: 29.09.2020 / Aceptado: 09.11.2020

DOI: https://doi.org/10.20318/cdt.2021.6004

\begin{abstract}
The prohibition of adoption is common to many Muslim jurisdictions; it passes directly from religious law into statutory law. The French PIL incorporates this provision by making, in principle, foreign minors of prohibitive status ineligible for adoption. The question arises whether such restriction is compatible with the right to respect for family life (article 8 ECHR). In Harroudj $v$ France, the ECtHR did not hesitate to respond in the affirmative. The paper revisits this judgment and concurs with what is deemed to be its ultimate finding, namely that a reduction on the level of satisfaction of the right to respect for family life may sometimes be justified as a token of tolerance or hospitality towards foreign 'cultural law'.
\end{abstract}

Keywords: adoption; family life (article 8 ECHR); Islamic law; kafala; private international law.

Résumé: L'interdiction de l'adoption est commune à de nombreuses juridictions musulmanes; elle passe directement du droit religieux au droit statutaire. Le droit international privé français incorpore cette disposition en rendant, en principe, inéligibles à l'adoption les mineurs étrangers de statut prohibitif. La question se pose de savoir si une telle restriction est compatible avec le droit au respect de la vie familiale (article 8 Convention EDH). Dans l'affaire Harroudj c France, la Cour EDH n'a pas hésité à répondre par l'affirmative. Ce travail revient sur l'arrêt et souscrit à ce qui est considéré comme sa conclusion ultime, à savoir qu'une réduction au niveau de satisfaction du droit au respect de la vie familiale peut parfois être justifiée comme gage de tolérance ou d'hospitalité envers le 'droit culturel' étranger.

Mots-clés: adoption; droit international privé; droit islamique; kafala; vie familiale (article 8 Convention $\mathrm{EDH})$.

Summary: I. Introduction. II. The Islamic prohibition of adoption within the French PIL. 1. Technique of the PIL ban on adoption. 2. Objective scope. 3. Subjective scope. III. Right to adopt and right to respect for family life under article 8 ECHR. 1. Connection with 'family life'. 2. Nature of the right. 3. Limits of the right. IV. Aim of the PIL ban on adoption. 1. Disregard for the child's interest. A) The interest of the child against adoption. B) The interest of the child for adoption. C) 
The interest of the child all things considered. 2. Commitment to the public interest. A) The Islamic state's backlash. B) The Islamic state's sovereignty. V. Proportionality of the PIL ban on adoption. 1. Margin of appreciation $v$ 'precedent'. 2. Margin of appreciation - scope. 3. Margin of appreciation - type: empirical and normative. 4. The backlash hypothesis and the legislature's leeway for empirical assessment. 5. The sovereignty thesis and the legislature's leeway for normative assessment. 6. Margin-breaking consensus in comparative law? 7. Margin-breaking consensus in international law? VI. Concluding remarks.

\section{Introduction}

\section{The Islamic prohibition of adoption}

Adoption (tabanni) is prohibited by the Sharia and by legislation

1. The prohibition of adoption is common to many Muslim jurisdictions; in fact, only Tunisia and Somalia stand out by regulating explicitly adoption. ${ }^{1}$ The prohibition passes straight from religious law into statutory law, as it becomes manifest in the above formulation of article 46 of the Algerian Family Code. ${ }^{2}$

2. The Sharia prohibition of adoption is inferred from Quran 33:4-5:

4. God has not assigned to any man two hearts within his breast [...] neither has He made your adopted sons your sons in fact. That is your own saying, the words of your mouths; but God speaks the truth, and guides on the way.

5. Call them after their true fathers; that is more equitable in the sight of God. If you know not who their fathers were, then they are your brothers in religion, and your clients. $[\ldots]^{3}$

What are the reasons behind God's will?

3. The classical reading of these verses relates them to the marriage of the Prophet with Zayneb, divorced wife of Zayd, who had himself been adopted by the Prophet before Islam. For this marriage the Prophet came under heavy criticism, on the basis that Quran 4:23 posed an impediment for the marriage of the (ex-)father-in-law with the (ex-)daughter-in-law. The revelation of the above verses resolved the complication; if the adopted son is not a 'son in fact', i.e. there is no (fictive) consanguinity with Zayd, then, similarly, the ex-wife of the adopted son is not the ex-wife of a 'son in fact', i.e. there is no (fictive) affinity with Zayneb, and the said marriage does not contravene the divine mandate. ${ }^{4}$

4. Against this view it is argued that the above verses do not logically connect to the issue of marriage. ${ }^{5}$ Quran 4:23 proclaims '[f]orbidden to you' the (ex-)wives of your natural sons ('your sons who are of your loins'), which, read e contrario, means that are 'not [f]orbidden to you' the (ex-)wives

\footnotetext{
${ }^{1}$ See N. YASSARI, "Adding by Choice: Adoption and Functional Equivalents in Islamic and Middle Eastern Law", The American Journal of Comparative Law, 63, 2015, pp. 927 et seq., especially pp. 944-947 (Tunisia) and pp. 947-948 (Somalia) (available at https://papers.ssrn.com/sol3/papers.cfm?abstract_id=2714359 accessed on 24 September 2020).

${ }^{2}$ For similar stipulations in the legislations of Morocco, Egypt, Kuwait, Yemen and Jordan see ibid, p. 949.

${ }^{3}$ The Koran Interpreted: A Translation by A.J. Arberry, London, George Allen and Unwin, 1955 (available at https:// archive.org/stream/ArberryKoran/Arberry-Koran_djvu.txt accessed on 24 September 2020). - All the citations to the Quran infra come from this translation.

${ }^{4}$ See e.g. E. LANDAU-TASSERON, "Adoption, acknowledgement of paternity and false genealogical claims in Arabian and Islamic societies", Bulletin of the School of Oriental and African Studies (SOAS), 66, 2003, pp. 169 et seq., especially pp. 169-170.

${ }^{5}$ D.S. Powers, Muhammad Is Not the Father of Any of Your Men. The Making of the Last Prophet, Philadelphia, University of Pennsylvania Press, 2009, pp. 44-48.
} 
of your adopted sons ('your sons who are not of your loins'); within this context, the marriage of the Prophet with Zayneb is irreprehensible. ${ }^{6}$ In reality, things differed only in the biblical tradition (Leviticus), according to which the taboo of incest was so broadly planned as to cover the (ex-)wives of any sons, natural or adopted. ${ }^{7}$ However, this was no more relevant in the last case, since Quran 33:37 had introduced expressis verbis a dispensation: ${ }^{8}$

When thou saidst to him whom God had blessed and thou hadst favoured. Keep thy wife to thyself, and fear God, and thou wast concealing within thyself what God should reveal, fearing other men; and God has better right for thee to fear Him. So when Zaid had accomplished what he would of her, then We gave her in marriage to thee, so that there should not be any fault in the believers, touching the wives of their adopted sons, when they have accomplished what they would of them; and God's commandment must be performed.

5. Importantly, despite the impression left from the sequential arrangement of verse 37 and verses 4-5 in the compilation of the Quran, verse 37 precedes chronologically verses $4-5,{ }^{9}$ to the effect that these cannot be aimed at the 'removal' of a ground that would have made -without them-the marriage of the Prophet with Zayneb defective.

6. D.S. Powers submits that verses 4-5 are the consequence of the key theological doctrine of the 'finality of prophecy', drawn from Quran 33:40. ${ }^{10}$ Quran 33:40 identifies Mohammad as 'the Seal of the Prophets' -the office of prophecy entrusted to him must be brought to a close with his death, forever. Seemingly, this qualification requires that he has no adult son (he 'is not the father of any one of your men') who might outlive him, in which case the office of prophecy passes to the adult son. ${ }^{11}$ Under these conditions, Mohammad will initially spell out the dissolution of Zayd's adoption ${ }^{12}$ and in turn receive verses 4-5 on the abolition of the institution of adoption. It is asserted that, although with the dissolution of the adoption the threat for the doctrine has already been 'eliminated' ${ }^{13}$ the abolition of the adoption is still 'necessitated' for the sake of the doctrine. ${ }^{14}$ But this is hardly convincing. ${ }^{15}$ In fact, the doctrine manages to explain the (ad hoc) legal act, whereas it fails to explain the (wider) legal reform and give an answer to the question under examination.

7. The prohibition of adoption might be seen as a part of the attempt to rearticulate the unifying element of the social order in the transition from the pre- to the post Islamic era. Before Islam, unity was based on the allegiance of the individuals to larger groups like tribes and clans. After Islam, unity should be based on the allegiance of the individuals to faith. ${ }^{16}$ Remarkably, the practice of adoption opposed such a project because it was perpetuating the old model -the old model depended on alliances that increased the size of the host group and enhanced its military force and economic resources; ${ }^{17}$ and although forging alliances did not entail adoption as a rule, adoption normally took place for this reason,

${ }^{6}$ Ibid, p. 45.

${ }^{7}$ Ibid, pp. 45-47.

${ }^{8}$ Ibid, pp. 43, 44, 46-47, 122-123.

${ }^{9} \mathrm{Ibid}, \mathrm{p} .58$.

${ }^{10} \mathrm{Ibid}$, pp. 50-63.

${ }^{11}$ Ibid, p. 53.

${ }^{12}$ Ibid, pp. 55, 57, 58, 59-61.

${ }^{13}$ Ibid, p. 58.

${ }^{14}$ Ibid, p. 231.

${ }^{15}$ Cf. also ibid, p. 62 (glossing over the objection).

${ }^{16}$ A. al-Azhary Sonbol, "Adoption in Islamic Society: A Historical Survey”, in E. Warnock Fernea (ed.), Children in the Muslim Middle East, Austin, University of Texas Press, 1995, pp. 45 et seq., especially p. 47; also, J. BARGACH, Orphans of Islam: Family, Abandonment, and Secret Adoption in Morocco, Lanham / Boulder / New York / Oxford, Rowman \& Littlefield Publishers, Inc., 2002, p. 52.

${ }^{17}$ See N. YASSARI, supra n. 1, pp. 932, 933 (with further references). 
i.e. the securing of additional loyalties by binding the adoptee and the offspring of the adoptee, present and future, to the host group. ${ }^{18}$

8. The historical approach has of course its own shortcomings. It does not capture the profound ground for the opposition of Islam to adoption, that is also valid outside the above historical context, once tribes and clans are swept by historical evolution. This has to do with the significance of lineage (nasab) as 'the backbone and most fundamental organizing principle in and of Muslim society', and as 'an identifying characteristic for claiming and embracing a Muslim identity', a God-sent 'blessing and grace' that must be kept "“clean and pure"" ${ }^{19}$ Adoption disrupts this representation, hence its prohibition in the Quran. ${ }^{20}$

\section{The substitute of kafala}

9. The Islamic teaching prioritises charity for vulnerable children, notably orphans and foundlings. ${ }^{21}$ At the same time, adoption is expelled from Islamic law. Admittedly, in the pre-Islamic setting, adoption had systematically worked 'for the welfare of the clan and tribe' rather than for the welfare of children in need. ${ }^{22} \mathrm{Be}$ it as it may, there was nothing inevitable about that. Had adoption been maintained -and its rationale reframed-, it 'would have alleviated some of the pressure with respect to caring' for this population. ${ }^{23}$ The pressure now had to fall entirely on other mechanisms capable of filling the gaps created by the absence of the adoption. ${ }^{24}$ One of these, ${ }^{25}$ the most prominent, is kafala, a form of foster care or guardianship, defined as the voluntary undertaking of an adult (the kafil) to assume the maintenance, education and protection of a minor (the makfoul), in the same manner as the parents would do for their children. ${ }^{26}$ In this sense, kafala bears strong resemblance with adoption. This notwithstanding, kafala is adjusted to the Quranic message and is not burdened with the 'excesses' of adoption: the former - unlike the latter- does not make someone else's child one's own child and does not lead to the falsification of bloodlines and natural order. ${ }^{27}$

\section{Harroudj v France}

10. Can states bound by the ECHR withhold the right to adopt in the name of the Islamic prohibition of adoption? The ECtHR took a stand on this issue twice, first in its 2012 judgment on the

\footnotetext{
${ }^{18}$ See $i b i d$, p. 933 (with further references).

${ }^{19}$ J. BARGACH, supra n. 16, pp. 56-57, 62, 58.

${ }^{20} \mathrm{Ibid}$, p. 62.

${ }^{21}$ See M. SAYED, "The Kafala of Islamic Law - How to Approach it in the West", in Essays in Honour of Michael Bogdan, Lund, Juristförlaget i Lund, 2013, pp. 507 et seq., especially pp. 511-513; F. KutTy, "Islamic 'Adoptions': Kafalah, Raadah, Istilhaq and the Best Interests of the Child", in R. Ballard, R. Cochran, N. Goodno And J. Milbrandt (eds.), The Intercountry Adoption Debate: Dialogues Across Disciplines, Newcastle upon Tyne, UK, Cambridge Scholars Publishing, 2015, pp. 526 et seq., especially pp. 552-554.

${ }^{22}$ N. YASSARI, supra n. 1, p. 934.

${ }^{23}$ F. KutTY, supra n. 21, p. 544.

${ }^{24}$ Ibid, p. 544.

${ }^{25}$ The other two are legal fictions producing effects of maternity (radaah) and paternity (istilhaq) (ibid, p. 545). Further on radaah and on istilhaq see ibid, pp. 545-547 and 547-551, respectively; also N. YASSARI, supra n. 1, pp. 939 and 939-941, respectively. Moreover, on the informal (de facto) 'adoption', called trebi, which is widespread in Maghreb, see A. BüCHLER AND E. SChNEIDER KAYASSEH, "Fostering and Adoption in Islamic Law - Under Consideration of the Laws of Morocco, Egypt, and the United Arab Emirates", Electronic Journal of Islamic and Middle Eastern Law (EJIMEL), 6, 2018, pp. 31 et seq., especially pp. 39-40 (available at https://www.zora.uzh.ch/id/eprint/157736/ accessed on 24 September 2020).

${ }^{26}$ See M. SAYED, supra n. 21, p. 513.

${ }^{27}$ See International Reference Centre for the Rights of Children Deprived of their Family (ISS/IRC), Fact Sheet No 51, Specific case Kafalah (available at https://www.iss-ssi.org/2007/Resource_Centre/Tronc_DI/documents/FactSheetNo51ENG.pdf accessed on 24 September 2020); K. O'Halloran, The Politics of Adoption. International Perspectives on Law, Policy and Practice, Dordrecht / Heidelberg / New York / London, Springer, 3rd edn., 2015, pp. 605, 621.
} 
case Harroudj $v$ France ${ }^{28}$ and second in its 2015 judgment on the case Chbihi Loudoudi and Others $v$ Belgium, ${ }^{29}$ concerning a kafala set up in Algeria and Morocco, which was impossible to convert to adoption in France and Belgium, respectively. This paper concentrates on Harroudj, while it also draws comparisons with Chbihi, when appropriate.

11. Harroudj originates from the refusal of the French authorities to allow the adoption of an abandoned Algerian baby girl of unknown parents, Hind, by a French national, Ms K. Harroudj. In a nutshell: ${ }^{30}$ In January 2004, the President of the Court of Boumerdès (Algeria) entrusted Hind -then, three months old- to Ms K. Harroudj under an arrangement of kafala and 'authorised' the first to leave with the second to settle in France. They arrived in France in February 2004 and ever since they had been living together. The request for the adoption followed in 2006; it was rejected by the Lyons Tribunal de Grande Instance, whereas the Lyons Court of Appeal and the Court of Cassation subsequently ratified this solution. As the French courts were in front of a case with an international character, they had to apply the French PIL rule relevant to adoption. The problem was that this rule makes the child ineligible for adoption, precisely because of article 46 of the Algerian Family Code.

12. The next parts will tackle the French PIL ban on adoption to present its technique and scope (II), demonstrate its relevance for the right to respect for family life (III), pinpoint its aim (IV) and review its proportionality $(\mathrm{V})$. The paper embarks on thorough research on all the above levels, engaging meaningfully with the existing human rights literature and especially with the work of R. ALEXY, A Theory of Constitutional Rights, ${ }^{31}$ from which it borrows essential analytical concepts and methodological tools on its way forward. Harroudj does not discern any mismatch of the French PIL ban on adoption with the ECHR, as we are about to see. In this way, it offers a rare example where the ECtHR considers certain sacrifices under the ECHR to be justified as a token of tolerance or hospitality of religious law (VI).

\section{The Islamic prohibition of adoption within the French PIL}

13. Law no 2001-111 of 6 February 2001 inserted in the title VIII of the first book of the French Civil Code (hereinafter FCC) a new chapter III, entitled 'du conflit des lois relatives à la filiation adoptive et de l'effet en France des adoptions prononcées à l'étranger', that contains articles 370-3 to 370-5. The provision of article 370-3 (2) is of importance to us. It reads:

Adoption of a foreign minor may not be ordered where his or her personal law prohibits that institution, unless the minor was born and resides habitually in France.

\section{Technique of the PIL ban on adoption}

14. Article 370-3 (2) FCC puts into effect within the French territory the prohibition of the Islamic law, statutory and religious (the two are intertwined). How is this accomplished? Interestingly, the French PIL does not designate as applicable the minor's personal law and its prohibition, but declares the prohibition itself whenever this is located in the minor's personal law. ${ }^{32}$ At first sight, one might remark that, whether we proceed indirectly through a conflict of law rule or directly through a material rule, we end up with the prohibition anyway and the technique used has zero practical impact. Yet this is inexact. Based on the classical conflict of law rule, the prohibition would have effect only after pas-

\footnotetext{
${ }^{28}$ Harroudj v France, no 43631/09, 4 October 2012.

${ }^{29}$ Chbihi Loudoudi et autres c Belgique, no 52265/10, 16 décembre 2014.

${ }^{30}$ For a detailed account of the circumstances of the case see Harroudj, $\S \S 5-14$.

${ }^{31}$ R. AleXY, A Theory of Constitutional Rights, New York, USA, OUP, 2010 (translated from German by J. Rivers).

${ }^{32}$ Article 370-2 (2) FCC is not a conflict of law rule (règle de conflit) but a material rule (règle matérielle) of PIL (M.-L. NIboyet and G. de Geoufre de la Pradelle, Droit international privé, Paris, LGDJ, 6th edn., 2017, p. 208, no 280).
} 
sing successfully the scrutiny of the French international public order ${ }^{33}$ Based on the material rule, the prohibition will have effect without such precondition, which is here devoid of sense, since here French substantive law takes command, and French substantive law is by no means 'supervised' by the French international public order, but, on the contrary, gives this notion its original shape and tenor. ${ }^{34}$

\section{Objective scope}

15. If the personal law of the minor prohibits only full adoption, then it goes without saying that simple adoption raises no issue in terms of article 370-3 (2) FCC. The question is whether this hypothesis holds true for the personal law of a minor coming from countries like Algeria and Morocco. According to a view initially taken by some French courts, the answer should be affirmative, on the argument that these countries provide for kafala, which can be considered as the Islamic form of simple adoption. Thus, simple adoption was usually granted on this basis. ${ }^{35}$

16. To put an end to this practice, the Chief Prosecutor laid appeal before the Court of Cassation in the interest of law against two such decisions of the Courts of Appeal of Reims and Toulouse. In 2006, the First Civil Division eventually quashed these with two decisions issued on the same day. ${ }^{36}$ The lower courts were held to have violated article 370-3 (2) FCC by not applying it in the cases of minors from Algeria and Morocco, although the Algerian and Moroccan legislations contain a general prohibition of adoption, full and simple. ${ }^{37}$ The attempt to single out simple adoption and portray the Algerian and Moroccan legislations as being well-disposed at least towards this distorted their position, as it proceeded from an incorrect equivalence of kafala with simple adoption. In (legal) reality, no equivalence of kafala with simple adoption exists. ${ }^{38}$ To be sure, the parentage with the original relatives is left intact in kafala and in simple adoption, whereas it is extinguished in full adoption. However, both simple adoption and full adoption imply the creation of a new filiation tie between adopter and adoptee -this overarching trait (missing from kafala) is the principal target of the Islamic prohibition! ${ }^{39}$

${ }^{33}$ Cf. infra at V.6 (n. 169).

${ }^{34}$ The French international public order is activated with the exceptions to the rule (see infra at 3 and at VI).

${ }^{35}$ See M.-C. Le Boursicot, "La Kafâla ou recueil légal des mineurs en droit musulman : une adoption sans filiation", Droit et Cultures, 59, 2010/1, pp. 283 et seq., especially p. 296 (available at https://journals.openedition.org/droitcultures/2138 accessed on 24 September 2020); Y.A. RoBLen, Le droit français confronté à la conception musulmane de la filiation, Thèse, Université de Grenoble, 2014, p. 284 (available at https://tel.archives-ouvertes.fr/tel-01124264/document accessed on 24 September 2020).

${ }^{36}$ See Cour de Cassation, 1re 10 octobre 2006, no 06-15264 and no 06-15265 (available at www.legifrance.gouv.fr accessed on 24 September 2020).

${ }^{37} \mathrm{Ibid}$; also, H. Fulchiron, “Adoption sur kafala ne vaut (à propos des arrêts Civ. 1re, 10 octobre 2006)”, Recueil Dalloz, 12,2007 , pp. 816 et seq., especially pp. 819-820.

${ }^{38} \mathrm{Ibid}$, pp. 818, 819; P. Murat, "Le refus de la transformation en adoption", Droit de la Famille - Revue Mensuelle LexisNexis Jurisclasseur, 2009, pp. 37 et seq., especially p. 37, no 5 and p. 38, no 8.

${ }^{39}$ The only way to see things otherwise is to erase (?) this legal effect from the concept of 'adoption'. See this attempt in N. YASSARI, supra n. 1; Id., "Recognizing Child Protection Measures in Middle Eastern Legal Systems as Equivalents to Adoption - a Fresh Look on Maghrebian Kafala, Iranian Sarparasti and Iraqi Damm", in European Parliament. Directorate General for Internal Policies. Policy Department C: Citizen's Rights and Constitutional Affairs, Adoption: Cross-Border Legal Issues - Workshop 1 December 2015, European Union, 2015, pp. 64 et seq. (available at http://www.europarl.europa.eu/ RegData/etudes/STUD/2015/536477/IPOL_STU(2015)536477_EN.pdf accessed on 24 September 2020). The author criticises the 'misapprehension' of the concept of 'adoption' prevailing in the Western jurisdictions and suggests a definition thereof that illuminates the 'essence of adoption', its 'lowest common denominator' that remains stable no matter what incidental traits adoption 'may or may not' display from one jurisdiction to the other (Adding..., pp. 941-943; Recognizing..., pp. 65-66). According to this view, '[adoption] is [...] a way to generate an enduring bond between the new parents and the child, whereby the new parents are entrusted with [...] custody, administration of financial affairs, choice of residency, maintenance [of the child]', or 'a social connection on the basis of an intimate, personal relationship and a choice by the new parents to raise and care for the child as their own' (Adding..., p. 943; Recognizing..., p. 66). It is against these 'essentialia adoptionis' that various Islamic institutions -kafala among them- organising the placement of the child in new homes are tested to find out whether they can qualify for adoption surrogates 'regardless of their labeling' (Adding..., pp. 943-962; Recognizing..., pp. 66-74). Even so, one cannot see how kafala is a suitable candidate here, when it does not share all the 'essentialia adoptionis'. Their 'func- 
17. The demarcation of kafala from adoption was recently confirmed in the preliminary ruling delivered by the Court of Justice of the European Union (CJEU) on 29 March 2019 in the case C-129/18 SM $v$ Entry Clearance Officer, UK Visa Section, ${ }^{40}$ after request from the Supreme Court of the UK (SCUK), concerning the interpretation of the Directive 2004/38/EC 'on the right of citizens of the Union and their family members to move and reside freely within the territory of the Member States'. The SCUK questioned -inter alia- whether a child under kafala of a Union citizen falls to be described as family member who is 'direct descendant' within the meaning of article 2 (2) (c) of the Directive, in which case the right to entry and residence in the host country is granted automatically, or as 'other family member' within the meaning of article 3 (2) (a) of the Directive, in which case the right to entry and residence in the host country is granted if additional conditions are satisfied, most notably if the person is 'dependant or member of the household of the Union citizen'. These additional conditions are both satisfied in the circumstances of kafala and the SCUK 'has little doubt' about it; but it is not willing to turn to article 3 'if in reality' article 2 should be implemented instead. The CJEU admits that the notion of 'direct descendant' requires 'an independent and uniform interpretation throughout the European Union' $(\S 50)$ and indeed a 'broad' one (§53), insofar as semantic canons and linguistic intuition permit it. In this context, it can be said that the adopted child has the place of direct descendant of the adoptive parent, whereas it is not the same for the child 'in custody' regarding the 'permanent legal guardian' (§ 55) and, more particularly, for the makfoul regarding the kafil (§ 56). These persons are not placed in 'descending and ascending lines', contrary to point 2.1.2. of the Communication from the Commission to the European Parliament and the Council on guidance for better transposition and application of Directive 2004/38, suggesting that 'descending and ascending lines' exist even without genealogical background and reference to filiation. ${ }^{41}$

\section{Subjective scope}

18. Article 370-3 (2) FCC applies on a 'foreign minor' of prohibitive status, 'unless the minor was born and resides habitually in France'. Therefore, there are three exceptions to this rule:

19. First, the PIL ban on adoption does not apply from the outset on a foreign minor of prohibitive status whose place of birth and habitual residence is France. This is not the case for the minor who meets none of the conditions because he was born abroad and his habitual residence is abroad, nor for the minor who meets only one of these because his habitual residence is in France but he was born abroad (as in Harroudj) or because he was born in France but his habitual residence is abroad -as the conjunction 'and' witnesses, the two conditions are cumulative and must concur to establish the exception. ${ }^{42}$

20. Second, the PIL ban on adoption ceases to apply when the minor of prohibitive status acquires the French nationality (irrespective of whether he/she keeps or loses his/her initial nationality ${ }^{43}$ ). Un-

tionalist' description produces a shift of emphasis on the axis of parental responsibility, but this is as far as it gets. No matter how downplayed, the change on the level of parentage remains persistently into the picture-adoption makes 'new parents', as it is conceded, and, what is more, this is the primary legal effect by whose virtue parental responsibility is further attributed, whereas in kafala we always have non-parents acting in loco parentis [the author, on her part, treats differently the Moroccan kafala, that is not considered adoption substitute because of lack of permanence (Adding..., pp. 950, 951; Recognizing..., pp. 67-68), and the Algerian kafala, that is considered adoption substitute despite lack of permanence (Adding..., pp. 952-954; Recognizing..., pp. 68-69), thus ending up to a highly controversial position, advocated on expediency grounds: 'for the sake of [the] recognition in a Western court' of -at least- the Algerian kafala (Adding..., p. 954; Recognizing..., p. 69)].

${ }^{40}$ Available at https://curia.europa.eu/ accessed on 24 September 2020.

${ }^{41}$ See also the Opinion of Advocate General C. SÁnchez-Bordona, delivered on 26 February 2019, Case C-129/18, SM v Entry Clearance Officer, UK Visa Section (available at https:/curia.europa.eu/ accessed on 24 September 2020).

${ }^{42}$ See also H. Fulchiron, supra n. 37, p. 817.

${ }^{43}$ See SÉnat. Commission des Lois, Rapport $n^{\circ} 164$ (2000-2001) fait par N. ABout, p. 24 (available at https://www.senat.fr/ rap/100-164/100-1641.pdf accessed on 24 September 2020); also, circulaire du 22 octobre 2014 relative aux effets juridiques du recueil légal en France, BOMJ n 2014-11 du 28 novembre 2014 - JUSC1416688C, p. 8 at n. 31 (available at http://circulaires. legifrance.gouv.fr/pdf/2014/11/cir_38976.pdf accessed on 24 September 2020). 
der article 21-12 no 1 FCC, the child has the right to become French citizen if it has been placed under the foster care of a French citizen by judicial decision -which can be a judicial decision of kafala- for a certain period. This period was initially set to 5 years, but it later dropped to 3 years on the occasion of the promulgation of law no 2016-297 of 14 March 2016 regarding the protection of the child. ${ }^{44}$

21. Third, the PIL ban on adoption ceases to apply when the minor of prohibitive status attains majority.

\section{Right to adopt and right to respect for family life under article 8 ECHR}

\section{Connection with 'family life'}

22. The applicant claimed that article 8 ECHR applied in her case in its limb concerning the 'right to respect for family life, ${ }^{45}$ from which a right to adopt-foreclosed to her in France- derives. The ECtHR recalled that the ECHR guarantees no right to respect for family life and, as a result, no right to adopt, just to satisfy the desire 'to found a family' ${ }^{46}$ It presupposes some family tie that adoption would safeguard and further develop. This might be a tie of two sorts, a mere de facto tie that adoption would vest with an original legal form ${ }^{47}$ or a de jure tie -especially a functioning one-that adoption would vest with a new legal form. The last scenario was confirmed in Harroudj, given the kafala arrangement and the continuous cohabitation of the kafil with the makfoul. ${ }^{48}$ Therefore, the complaint was compatible with the ECHR ratione materiae. ${ }^{49}$

\section{Nature of the right}

23. The ECtHR then examined the complaint 'in terms of positive obligations' of the state. ${ }^{50}$ This stance should be approved. From the word 'respect' mentioned in article $8 \S 1$ ECHR ensue state obligations for negative action and state obligations for positive action..$^{51}$ There are, accordingly, two types of rights against the state, 'defensive rights' and 'performance rights', ${ }^{52}$ and indeed not only rights to factual performance but also rights to normative performance, ${ }^{53}$ a subcategory embracing -inter aliarights to private law 'competences' or 'powers' by which individuals are enabled to engage in 'institutional acts' and alter private law positions. ${ }^{54}$ Such are, for example, the right to marry, the right to divorce, the right to acknowledge and to contest paternity or the right to adopt.

${ }^{44}$ See article 42 amending article $21-12$ no 1 FCC.

${ }^{45}$ Harroudj, § 28. Cf. Chbihi, § 72.

${ }^{46}$ Harroudj, $\S 41$ and in the same sense also e.g. Fretté v France, no 36515/97, 26 February 2002, § 32; E.B. v France, no 43546/02, 22 January 2008, § 41 (citing exceptions to the rule); Gas and Dubois v France, no 25951/07, 15 March 2012 , § 37.

${ }^{47}$ On this see G. Letsas, "No Human Right to Adopt?", UCL Human Rights Review, 1, 2008, pp. 135 et seq., especially pp. 142, 153.

${ }^{48}$ See Harroudj, $\S \S 46,35$.

${ }^{49}$ It sounds correct that the right to adopt may also be seen as an aspect of the 'right to respect for private life', which is 'a broad concept that encompasses [...] the right to establish and develop relationships with other human beings [...] and both the decisions to have or not have a child' [see E.B., $\S 43$, although the ECtHR concludes with an enigmatic position as regards the right to adopt and the ambit of 'private life', holding that the right will fall within the ambit when article 8 ECHR is taken in conjunction with article 14 ECHR (E.B., $\S \S 41-45,47-52)$, but it may fall outside the ambit when article 8 ECHR is taken alone (E.B., § 46)! On such 'flexible "ambit" test' see J. Gerards, "Chapter 30. Prohibition of Discrimination (Article 14 and Article 1 of Protocol No. 12)", in P. van DiJk, F. van Hoof, A. van RiJn and L. Zwaak (eds.), Theory and Practice of the European Convention on Human Rights, Cambridge / Antwerp / Portland, Intersentia, 5th edn., 2018, pp. 997 et seq., especially p. 1000].

${ }^{50}$ Harroudj, § 47; also, Chbihi, § 90.

${ }^{51}$ Marckx v Belgium, no 6833/74, 13 June 1979, § 31.

${ }^{52}$ R. Alexy, supra n. 31, pp. 122-126 and 126-127, respectively.

${ }^{53}$ Ibid, pp. 126-127, 294-296.

${ }^{54}$ Ibid, pp. 149-159, 324-326. 
24. A similar pattern is observable in Wagner and J.M.W.L. v Luxembourg, ${ }^{55}$ where the issue faced by the forum was the enforcement of a foreign adoption and not the adoption per se. Surprisingly, the ECtHR approached this 'from the aspect of a negative obligation' of the forum ${ }^{56}$ and, consequently, contrasted Harroudj (and Chbihi) with Wagner. ${ }^{57}$ In substance, though, there is no structural difference between the request for recognition of an acquired status, as in Wagner, and the request for constitution of a new status, as in Harroudj (and Chbihi), by the forum. In both instances, the legal positions of adopter and adoptee are absent within the domestic legal order and the request is precisely for the forum to take action to release legal consequences of adoptive filiation. In this regard, one might perhaps perceive a 'less' or a 'more' energetic contribution of the forum, depending on whether its action extends the acquired status (recognition) or builds the new status from scratch (constitution). In any event, one should not forget that it is always about positive, norm-enacting action, granting the stakeholders the right to reach the court and bring about a status-conferring ruling. At no point is the abstinence of the forum efficient. ${ }^{58}$

\section{Limits of the right}

25. The effect of article 370-3 (2) FCC is the negation of the applicant's competence or power -i.e. her 'disability" ${ }^{59}$ - to adopt. Yet the article 8 ECHR right is not absolute. Some justification may exist under which the disability comes off as the consequence of a mere limitation and not a violation (infringement, breach) of the right to respect for family life. ${ }^{60}$

26. As the division of article 8 ECHR in its two paragraphs suggests, the right to respect for private and family life is a 'two-stage' right, one marked by the 'bifurcation' of scope (paragraph 1) and limiting clause (paragraph 2). ${ }^{61}$ To illustrate the key points of the idea: On the first level, the field of the prima facie right is circumscribed and the situations in which an interference with this takes place are highlighted. On the second level, in presence of an interference, all reasons for and against protection ('respect') are put on the scales to reach a definitive conclusion about the application of the limiting clause. In particular: either there is a case for protection, meaning that the interference is not covered by the clause and the prima facie right turns into a definitive right; or there is a case against protection, meaning that the interference is covered by the clause and the prima facie right turns into a definitive no-right. ${ }^{62}$ Two ought-judgments (on prima facie and definitive ought) decide on the norm emerging from article 8 ECHR.

27. However, the above scheme has been strictly tied to negative rights and obligations; when it comes to positive rights and obligations, the division is abandoned. The ECtHR is adamant that the

\footnotetext{
${ }^{55}$ Wagner and J.M.W.L. v Luxembourg, no 76240/01, 28 June 2007.

${ }^{56} \mathrm{Ibid}, \S 123$.

${ }^{57}$ Harroudj, § 47; Chbihi, § 91.

${ }^{58} \mathrm{Of}$ course, once the status is conferred (through judicial recognition or constitution), the next question concerns the right of its occupants to keep it. Still, there are two ways to see this, either as a right to a negative action of the legislature (non-removal of status) or as a right to a positive action of the legislature (maintaining-in-force of status) (R. ALEXY, supra n. 31, p. 127 at n. 72 and p. 320). - However, the above do not have the meaning that a request for status recognition and a request for status constitution are to be treated alike (see infra at V.1).

${ }^{59} \mathrm{Ibid}, \mathrm{pp} .151,155$.

${ }^{60}$ On the distinction between Einschränkung and Verletzung of the right see ibid, pp. 180, 182.

${ }^{61}$ J. Gerards And H. Senden, "The structure of fundamental rights and the European Court of Human Rights", International Journal of Constitutional Law (ICON), 7, 2009, pp. 619 et seq.; also, G. VAN DER SCHYFF, "Interpreting the protection guaranteed by two-stage rights in the European Convention on Human Rights: The case for wide interpretation" and L. LAVRYSEN, "The scope of rights and the scope of obligations: Positive obligations", as these texts feature in E. BREMS AND J. GERARDS (eds.), Shaping Rights in the ECHR: the Role of the European Court of Human Rights in Determining the Scope of Human Rights, New York, USA, CUP, 2013, at pp. 65 et seq. and 162 et seq., respectively.

${ }^{62}$ R. Alexy, supra n. 31, pp. 181-184 and especially pp. 183, 184. On the prima facie and definitive character of principles more generally see $i b i d$, p. 57 .
} 
positive modality of 'respect' of paragraph 1 'is not clear cut' and 'the notion's requirements will vary considerably from case to case' ${ }^{63}$ Only after having struck a 'fair balance' of the reasons weighing for and against the positive right does it become possible to say 'whether or not a positive right exists ${ }^{\prime 64}$ and a state omission -such as the failure to grant the right to adopt- falls under its scope. If reasons for respect prevail, a positive right exists and the omission is unjustified. This is a case of violation of the right. If reasons against respect prevail, no positive right exists and the omission is justified. This is a case of limitation of the right, albeit in a metaphorical sense: ${ }^{65}$ limitation is here anything but definition, what delineates the right's own 'extent' or 'content' ${ }^{66}$ Whatever is the upshot (violation or limitation), this is already determined within paragraph 1 , 'without there being any call to examine it under paragraph 2'. ${ }^{67}$

28. This approach is rightfully criticised. ${ }^{68}$ First, it is not persuasive how the same provision (article 8 ECHR), common sedes materiae for the negative and the positive right to respect for private and family life, requires different formal frameworks for the description of each of them and allows room for wide and narrow theories of scope of right ${ }^{69}$ to operate side by side. Second, the construction of the positive right is practically problematic in itself, regarding the applicable conditions of limitation. These do not coincide exactly with the corresponding ones of paragraph 2, which would have simply shifted to the environment of paragraph 1 . The discussion here takes another turn, as the rigorous three-pronged test asking whether a state action (in the context of the negative right) is (a) 'in accordance with the law', (b) whether it is directed towards a specific legitimate aim picked among 'national security', 'public safety or the economic well-being of the country', 'the prevention of disorder or crime', the 'protection of health or morals' or 'the protection of the rights and freedoms of others', and (c) whether it is 'necessary in a democratic society', is reduced to point (c) whenever a state omission (in the context of the positive right) is concerned..$^{70}$ Importantly, thus, 'fair balance' or 'proportionality' suffices and the fact that point (a) or/and point (b) may not be satisfied is inconclusive. This renders two extra safeguards set against state action pointless against state omission.

29. For these reasons, it would be preferable if the ECtHR rejected the "negative/positive dichotomy' and used a unified methodology for the negative and the positive right. ${ }^{71}$ However, this is not how things stand at present. The analysis is bound to deal with a choice steadily made in the previous case law $^{72}$ and reiterated in Harroudj (and Chbihi) without reservation. ${ }^{73}$

\footnotetext{
${ }^{63}$ Harroudj, § 47.

${ }^{64} \mathrm{Ibid}, \S 47$.

${ }^{65}$ As pointed out by R. AleXY, supra n. 31, p. 181 at n. 11.

${ }^{66}$ The limitation is 'immanent' (ibid, p. 179).

${ }^{67}$ So, paradigmatically, Marckx, supra $\mathrm{n} .51, \S 31$. - In this connection, it seems reasonable -at least up to a certain point; see immediately infra- that the ECtHR shows reluctance to understand state omission as 'interference' with the right to respect for family life (Harroudj, § 47; Chbihi, § 90; Marckx, supra n. 51, § 31). It makes little sense to speak of 'interference' with something which is still unknown 'whether or not exists'. Since the object of prima facie right is unavailable and one must proceed exclusively on the basis of definitive positions, what triggers the interplay of reason and counter-reason leading to the definitive positions (rights or no-rights) cannot be labelled invariably 'interference'. State omission is such in the first scenario -individuals suffer interference with rights they have. State omission is not such in the second scenario -individuals do not suffer interference with rights they have not. Qualification is revealed through balancing (cf. R. ALEXY, supra n. 31, pp. 180, 182).

${ }^{68}$ L. Wildhaber and S. Breitenmoser, Internationaler Kommentar zur EMRK, Köln, Carl Heymanns Verlag, 1992, Art. 8 nos 13, 14, 55-60, 75 and the concurring opinion of judge L. WiLDHABER in Stjerna $v$ Finland, no 18131/91, 25 November 1994. In the same vein, more recently: J. GERARDS AND H. SENDEN, supra n. 61, pp. 634-653; G. vAN DER SChYFF, supra n. 61, pp. 77-82; L. LAVRYSEN, supra n. 61, passim.

${ }^{69}$ On these see R. AleXY, supra n. 31, pp. 200-217.

${ }^{70}$ L. Lavrysen, "Chapter 4. System of Restrictions", in P. van Dijk, F. van Hoof, A. van Rijn and L. ZwaAk (eds.), Theory and Practice of the European Convention on Human Rights, Cambridge / Antwerp / Portland, Intersentia, 5th edn., 2018, pp. 307 et seq., especially p. 325.

${ }^{71}$ See the authors supra n. 68 and foremost the concurring opinion of judge L. WILDHABER in Stjerna $v$ Finland, no 18131/91, 25 November 1994.

${ }^{72}$ See after Marckx, supra n. 51, indicatively, Rees $v$ The United Kingdom, no 9532/81, 17 October 1986, § 37; Hatton and Others $v$ The United Kingdom, no 36022/97, 8 July 2003, § 98.

${ }^{73}$ In any event, the PIL ban on adoption satisfies point (a) and point (b) of article $8 \S 2$ ECHR. As to point (a), the PIL ban
} 


\section{Aim of the PIL ban on adoption}

\section{Disregard for the child's interest}

30. Having read Harroudj, one is rather convinced that article 370-3 (2) FCC does not work in the interest of the child in the instant case (Hind), nor of any other child found in an analogous position. The following lines will try to elaborate this insight. The analysis takes note that the interest of the child is multifaceted, it organises the arguments for and against adoption and finally draws up a 'balance sheet' of the 'pros' and the 'cons', showing that the adoption would do more good than bad to the child -a missed opportunity because of article 370-3 (2) FCC.

\section{A) The interest of the child against adoption}

31. In a situation of international displacement, the child has an interest in the continuity of its legal status and cultural identity. As suggested, the PIL should adjust to this 'spatial' or 'conflictual' interest to promote the 'international welfare' ('bien-être international') of the child. ${ }^{74}$ This is the task that article 370-3 (2) FCC sets to accomplish with the prohibition of adoption. ${ }^{75}$ In particular:

32. First, adoption is considered problematic because it leads to the establishment of a limping family relationship. Indeed, the adoptive filiation would be valid in France and invalid in the country of origin, where it is not merely unregulated but it is moreover anathema; therefore, the child would be divided between different personal status in different places. This 'pitfall' is sidestepped with the maintenance of kafala, a uniform personal status that the child enjoys both in France and in the country of origin. ${ }^{76}$

33. Second, adoption is considered problematic because it runs contrary to the child's cultural identity. The idea is that provisions like article 46 of the Algerian Family Code are not reducible to mere 'technical rules', akin to those that govern tenancy or transfer of property, just to mention a few, but they are rather 'cultural rules', ${ }^{77}$ ingrained in the religious tradition that they faithfully reflect by duplicating the Quranic prohibition of adoption. ${ }^{78}$ In this light, the adoption of the child is not so straightforward in terms of its cultural identity if the latter is also modelled by 'cultural rules' ${ }^{79}$ The objection is that the application of Western norms conflicting with Islamic norms of such kind compromises the child's cultural development and, even worse, appears as an attempt to reverse this already undergoing process by 'forced assimilation' ('forcierte Assimilierung'). ${ }^{80}$ In conclusion, 'the most appropriate legal institution', capable of fully supporting the child's bond with its origins, is not offered by Western law but by Islamic law; it is not the adoption but the kafala. ${ }^{81}$

has an accessible and precise basis in national law (article 370-3 (2) FCC), displaying all the necessary elements of the "quality of law'. As to point (b), some part of the public interest furthered by the PIL ban intersects with the 'protection of the rights and freedoms of others' (see infra at IV.2.A) in fine).

${ }^{74}$ P. Hаммле, "L'intérêt de l'enfant face aux sources internationales du droit international privé", in Le droit international privé: esprit et méthodes. Mélanges en l'honneur de Paul Lagarde, Paris, Dalloz, 2005, pp. 365 et seq., especially pp. 368-375.

${ }^{75}$ P. Hammse, "L'interdiction d'adoption face aux droits fondamentaux", Recueil Dalloz, 43, 2012, pp. 2947 et seq., especially p. 2949, no 10

${ }^{76}$ Cour de CASSATION, Rapport annuel 2013. L'ordre public, p. 472 (available at https://www.courdecassation.fr/publications_26/rapport_annuel_36/rapport_2013_6615/ accessed on 24 September 2020).

${ }^{77}$ On the distinction between 'technische Regeln' and 'kulturelle Regeln' see E. JAYME, "Die kulturelle Dimension des Rechts - ihre Bedeutung für das Internationale Privatrecht und die Rechtsvergleichung”, Rabels Zeitschrift für ausländisches und internationales Privatrecht (RabelsZ), 67, 2003, pp. 211 et seq., especially p. 219.

${ }^{78} \mathrm{Ibid}$, p. 217; E. JAYME, "Kulturelle Identität und Kindeswohl im internationalen Kindschaftsrecht”, Praxis des Internationalen Privat- und Verfahrensrechts (IPRax), 4, 1996, pp. 237 et seq., especially pp. 238-239.

${ }^{79}$ E. JAYME, supra n. 77, p. 217; Id., supra n. 78, pp. 238-239.

${ }^{80}$ E. JAYME, supra n. 78, p. 238.

${ }^{81}$ E. JAYME, supra n. 77, p. 217; Id., supra n. 78, p. 239. - The problem for the cultural identity of the child is aggravated when adoption is a reason for the termination of kafala or/and the removal of nationality in the country of origin. This is not 
34. However, the previous description of the 'spatial' interest of the child to avoid adoption because adoption brings on a limping personal status and alteration of the cultural identity- moves on an abstract plane. One has to go beyond this and ask what is the significance of these -by definition, negative- effects for the concrete child, based on its specific circumstances and characteristics? These factors determine the interest of the child in the 'substantial' or 'material' sense ${ }^{82}$ that is called to evaluate the causes of concern spotted so far under real-life conditions. At the end of the day, this is all that matters. Concerns on the 'spatial' level can be taken into consideration only if they are also relevant to the 'material' level, i.e. if the spatial and the material interest overlap. Otherwise, 'spatially' salient but 'materially' indifferent concerns should be discounted as merely speculative.

35. The profile of the child in Harroudj is familiar: she is an abandoned makfoul of unknown parents in Algeria that she left when she was three months old to stay permanently with her kafil in France. ${ }^{83}$

36. Within this context, the child is not immune to the aforementioned risks just because no ties with the home country exist. This does not rule out the possibility of future harm: First, the child may be exposed to the trauma of limping status if she visits or relocates to her home country. Second, the child may be exposed to the trauma of alteration of cultural identity as cultural precepts are passed down to her by her caregiver -'a sensible and honest Muslim', as the Algerian court has found her to be, applying article 118 of the Algerian Family Code- and she discovers her religious and national heritage away from her home country.

37. On the other hand, the absence of ties makes a difference and the child is relatively shielded from risks on both levels. On the first, contact with the home country seems statistically rare; and even in this contingency, the ramifications induced by the denial of adoption shall consist in administrative difficulties alone, with no dispute being raised by the biological mother or father, willing to claim their rights over the child. On the second, one might wonder how deep can go the trauma that adoption signifies for the cultural identity, when the child experiences it precisely through the lens of cultural precepts learned from a Muslim with a liberal outlook on adoption, a Muslim who pursued her adoption.

38. In sum, some risks remain (small or great, it is not the issue for now) that underpin a certain material interest of the child against adoption.

\section{B) The interest of the child for adoption}

39. The flip side of the coin is that adoption can also advantage the child in several respects.

40. Primarily, adoption creates parentage there where only foster care exists: the relationship of kafil and makfoul is upgraded into a more fundamental relationship of father or mother and son or daughter, as the case may be.

41. Moreover, there are secondary-reflex legal effects, associated with parentage. Some of them reach further than the legal effects of kafala, even if these were recognised in France in their totality. ${ }^{84}$ Still, adoption confers French nationality automatically or makes French nationality accessible sooner

\footnotetext{
the case in Harroudj because the Algerian legislation appears mild in this regard. But these extra parameters should be given consideration, for example, when the child comes from Morocco (where adoption may lead to the termination of kafala) or Egypt (where adoption may lead to the removal of nationality).

${ }^{82}$ P. Haмmse, supra n. 74, pp. 376-381.

${ }^{83}$ See supra at I.

${ }^{84}$ Which is not actually the case; see infra at V.1 in fine.
} 
by declaration, ${ }^{85}$ it gives a more safe solution for residence in France, ${ }^{86}$ it entitles to more social benefits $^{87}$ and, last but not least, it entails rights of the adoptee on the estate of the adopter by operation of law, namely rights of succession ab intestat or succession to a reserved portion.

42. Notably, all the above are also important for the psychological well-being of the child, as, first they inspire to the child a sense of security and stability, and second they assist the child to build identity as member of the new family and community, equal to anyone else enjoying the same treatment in the host country.

\section{C) The interest of the child all things considered}

43. In this section, the conflicting interests of the child regarding adoption will be put on the scales to assess their weight and compare them to each other. ${ }^{88}$ If the losses from being adopted outstrip gains, then the child has an interest contra adoption all things considered. If the gains from being adopted outstrip losses, then the child has an interest pro adoption all things considered. The balancing should offset some values on both sides and result in a residual quantity, negative or positive, that determines which option (contra or pro adoption) meets the best interest of the child. ${ }^{89}$

44. It can be maintained that, under the conditions presented above, the child would be overall better off with the adoption than without it. The risks for the continuity of status and cultural identity are not decisive for the outcome of balancing.

45. As regards the (confined) $)^{90}$ risk of harm from the limping status, this is 'tolerable' and 'admissible', ${ }^{91}$ given the improvement that the adoption means for the child on the many levels of parentage, nationality, social benefits, succession rights, and psychological enhancement. ${ }^{92}$

46. As regards the (confined) ${ }^{93}$ risk of harm from the alteration of the cultural identity, this is defeated on its own terrain. It has to be born in mind that the individual cultural identity is not necessarily uniform; more often than not, it comes up as a constellation of multiple collective identities from which the individual draws during its course of life. ${ }^{94}$ This also applies in Harroudj, where the child identifies in tandem with the country of origin and the receiving country, while these identifications pull to different directions $v i s-\grave{a}-v i s$ the prohibition or the permission of its adoption. The prohibition will expand the original cultural identity and detract from the French counterpart. The permission will expand the

\footnotetext{
${ }^{85}$ See articles 20 (2) FCC (on full adoption) and 21-12 (1) FCC (on simple adoption), respectively.

${ }^{86}$ See generally O. Dubos, "La kafala et le juge administratif : court séjour au pays de l’insécurité juridique", Droit de la Famille - Revue Mensuelle LexisNexis Jurisclasseur, 2009, pp. 22 et seq.

87 See generally M. Badel and O. Pujolar, "Kafala et droits sociaux", Droit de la Famille - Revue Mensuelle LexisNexis Jurisclasseur, 2009, pp. 25 et seq.

${ }^{88}$ On the need of balancing see the remarkable ReZ (A Child) (Egyptian fostering UK adoption) [2016] EWHC 2963 (Fam) [Russell], paras 113-114 (quoting other relevant authorities) (available at https://www.familylawweek.co.uk/site.aspx?i=ed168798 accessed on 24 September 2020) and S. BollÉE, "La conformité à la Convention européenne des droits de l'homme de l'interdiction d'adopter un enfant recueilli en kafala (Cour eur. dr. h., Harroudj c. France, 4 octobre 2012)", Revue Trimestrielle des Droits de l'Homme, 95, 2013, pp. 717 et seq., especially p. 723.

${ }^{89}$ Of course, a stalemate between the options pro and contra adoption cannot be excluded beforehand.

${ }^{90}$ See supra at IV.1.A) in fine.

${ }^{91}$ H. Muir WATt, "La loi nationale de l'enfant comme métaphore : le nouveau régime législatif de l'adoption internationale", Journal du Droit International (Clunet), 4, 2001, pp. 995 et seq., especially pp. 1019-1020.

${ }^{92}$ In this connection, it is emphasised that the consequence of limping status does not impede the acknowledgment of paternity of the Muslim child, even if the judgment of acknowledgment of paternity has no more chances than the judgment of adoption to be recognised in the country of origin (ibid, p. 1019 at n. 98).

${ }^{93}$ See supra at IV.1.A) in fine.

${ }^{94} \mathrm{~L}$. CANnAgÉ, Les méthodes du droit international privé á l'épreuve des conflits de cultures, Maubeuge, France, ADIPoche, 2013, p. 26, no 12 and p. 28, no 14.
} 
French cultural identity and detract from the original counterpart. This tension, internal to the configuration of the individual cultural identity, is resolved -in the child's interest- by reasoning in terms of 'proximity' and by subjecting the issue to the law of the country with which the child has stronger attachments. ${ }^{95}$ In this connection, the lack of a family in the country of origin as against the existence of a family in the receiving country, and the short past in the country of origin as against the future ahead in the receiving country attest to a 'shift of balance' in favour of the law of the receiving country as the most adequate to protect the child's self-perception and sentiment of belonging. ${ }^{96}$

47. Likewise, nothing changes when the two objections to the adoption join forces and cease being considered separately.

48. After all, the French legislator himself weighs in and dismisses these objections when he introduces exceptions to the PIL ban on adoption for some foreign minors of prohibitive status if they were born and reside habitually in France or if they were under foster care for 3 years and have become citizens of France..$^{97}$ The risks of limping status and alteration of the cultural identity, if adoption proceeds, are the same for them as for the rest of the group who do not possess such characteristics!

49. As a last remark, let it be clarified that no additional objection to the adoption exists from the point of view of the child in Harroudj, despite the contention set forth in the judgment that children falling under article 370-3 (2) FCC are in an uncertain phase, during which the need emerges 'to encourage the[ir] integration [into French society] without cutting them off immediately from the rules of their country of origin ${ }^{\prime}{ }^{98}$ This is an overgeneralisation. In essence, children falling under article 370-3 (2) FCC are a heterogeneous aggregate. The concern is valid for those of them who arrive in France at a late stage of their lives, parting from their parents in the country of origin (and the same goes for late comers orphaned youngsters). The concern is not valid for those of them who arrive in France at an early stage of their lives, having been abandoned by their parents in the country of origin (and the same goes for early comers orphaned babies). Regarding the last subcategory, the PIL ban on adoption is unamenable to an explanation relevant to the interest that someone would supposedly have in being guided 'gradually' to the path of adoption. ${ }^{99}$

\section{Commitment to the public interest}

50. If the restriction of the right to adopt does not serve the interest of the child of prohibitive status, then what is left is to correlate it with the 'public interest'100 or the 'general interest of the community'. ${ }^{101}$ What does this collective interest refer to? This seems to be relevant to policy considerations well summarised in the French Senate's approval of the PIL ban on adoption on the grounds that '[it was not] desirable to impose unilaterally the application of the French law to foreign States cultivating a conception opposite to ours '. ${ }^{102}$ The diplomatic concern here remains vague, but its linkage with more concrete reasons is possible. There are two such reasons. A first explanation is that we must refrain

${ }^{95}$ P. Hammse, supra n. 74, pp. 372-375.

${ }^{96}$ H. Muir WaTt, supra n. 91, pp. 1006-1007 (especially p. 1007: 'changement d'equilibre').

${ }^{97}$ See supra at II.3.

${ }^{98}$ Harroudj, $\S 51$. According to the ECtHR, 'objective signs of [...] integration into French society' are missing in the beginning and can only be seen over time. The argument of the French Government is in the same sense, namely that a period of delay should work as a testing period for the viability of adoption (rather so, ibid, § 39).

${ }^{99}$ See also N. Hervieu, "L'adoption internationale aux prises avec la kafala sous le regard européen", Lettre "Actualités Droits-Libertés » du CREDOF, 8 octobre 2012 (available at https://revdh.wordpress.com/2012/10/08/adoption-internationale-kafala-regard-europeen/ accessed on 24 September 2020).

${ }^{100}$ Harroudj, $\S 51$.

${ }^{101} \mathrm{Ibid}, \S 47$.

${ }^{102}$ Sénat. Commission des Lois, supra n. 43, p. 23 and, in the same vein, Cour DE CASSATIOn, supra n. 76, p. 472: article 370-3 (2) FCC 'is aimed at not imposing unilaterally a European conception of adoption'. 
from imposing our law on the Islamic states because we worry about their backlash. The imposition could be counterproductive. A second explanation is that we must refrain from imposing our law on the Islamic states because we respect their sovereignty. The imposition would be inherently wrong. In other words, the PIL ban on adoption may show up as an 'instrumentally-rational' (Zweckrational) or as a 'value-rational' (Wertrational) legal effect, depending on the angle of view and the rationality attributed to the legislative action. ${ }^{103}$ We will examine these points in turn. ${ }^{104}$

\section{A) The Islamic state's backlash}

51. It is not uncommon for intended parents to set out to establish a kafala in a country where adoption is prohibited, just to be entitled to take the child in their country where adoption is permitted and seek there the transformation of the kafala into adoption. If the plan can go ahead without sanction in the permissive country, then it pays off at the expense of the prohibitive country, for which the situation lies beyond its control as soon as it passes its borders. Under such conditions, its only alternative is self-defense: the denial of inter-country kafala when this is anticipated to serve as the antechamber of adoption.

52. A case in point is the circular no $40 \mathrm{~S} / 2$ of 2012, issued by the Ministry of Justice and Liberties in Morocco. ${ }^{105}$ The circular instructed the prosecutors at the courts of appeals and the first instance courts to detect the applications for kafala submitted by foreigners with residence abroad ${ }^{106}$ and bring this to the attention of the competent judges to reject the applications. The major reason of the circular is that compliance with the law no 15-01 of 13th of June 2002 'concerning the care (kafala) of abandoned children' cannot be ensured due to the difficulty of collecting reliable information about foreign residents. Thus, as it is impossible to assess ex ante or to follow-up their performance in the exercise of their duties (as per articles 16 and 19, respectively), the chances increase for the court to err and either award a kafala where it should not do so or not revoke a kafala where it should do so, leaving the child in the hands of incompetent persons (notably those failing to provide for the Islamic education and upbringing of the child). On top of that, even if all these thoughts causing disquiet are set aside, there is always the suspicion of 'denaturalisation of the institution of kafala' through the adoption of the makfoul by the kafil. ${ }^{107}$ Therefore, it transpires that the problem with inter-country kafala may be more complex than the opening paragraph described it.

53. The reception of the circular by the judges was unequal. ${ }^{108}$ On some occasions they continued, as before, to examine the sufficiency of the evidence before them on the applicants' ability and

\footnotetext{
${ }^{103}$ On these ideal types expressing different ways of orientation of the social action in general see M. WEBER, Economy and Society. An Outline of Interpretive Sociology, edited by G. Rотн And C. Wiтtich, Berkeley / Los Angeles / London, University of California Press, 1978, pp. 24-25.

${ }^{104}$ There have been de lege ferenda proposals to make a child of prohibitive status immediately adoptable when it has been abandoned (Y.A. RoBleh, supra n. 35, pp. 315-317) or has its habitual residence in France [Groupe DE travail « Protection DE L'ENFANCE ET ADOPTION », 40 propositions pour adapter la protection de l'enfance et l'adoption aux realités d'aujourd'hui, présidé par A. Gouttenoire, Ministère des affaires sociales et de la santé. Ministère délégué chargé de la famille, 2014, pp. 92, 94 (Proposition no 30) (available at https://www.vie-publique.fr/sites/default/files/rapport/pdf/144000303.pdf accessed on 24 September 2020)]. Interestingly enough, these proposals do not go so far as to accept full adoption, but only consider simple adoption (Y.A. Robleh, supra n. 35, pp. 317-318; Groupe DE TRAVAIL..., pp. 92, 94), with a view to embarrass as little as possible the country of origin (Y.A. RoBLEH, supra n. 35, p. 318; Groupe DE TRAVAIL..., p. 92). What follows in the main text accounts also for such cautious approaches.

${ }^{105}$ Available (in French) at http://www.kafala.fr/la-kafala/circulaire accessed on 24 September 2020.

${ }^{106}$ The circular does not extend to Moroccans with residence abroad, according to the explication offered by the Ministry in the letter no 6902 of 20 November 2012 (ibid).

${ }^{107}$ See H. Brahimi of the Ministry, at the workshop organised by the Centre Unesco Droits et Migrations, at Rabat, on 22 December 2013, on the topic « Problématique du contrôle et du suivi des enfants Makfouls par des familles au Maroc et à l'étranger » (available at http://cudm.net/problematique-du-controle-et-du-suivi-des-enfants-makfouls-par-des-familles-aumaroc-et-a-letranger/ accessed on 24 September 2020).

${ }^{108}$ Cf. K.E. Hoffman, "Morocco", in N. Yassari, L.M. Möller and M.C. Najm (eds.), Filiation and the Protection of Parentless Children. Towards a Social Definition of the Family in Muslim Jurisdictions, The Hague, The Netherlands, Springer, 2019, pp. 231 et seq., especially p. 260.
} 
good faith, according to their intimate conviction. On other occasions they hardened their stance. The impact was especially felt by applicants who, at the time of the change of policy, had embarked on a procedure of kafala and had been assigned children within this framework. It is reported that several pending cases involving Spanish citizens were unblocked only after the Spanish government pledged to address the critical issues raised by Morocco, namely to facilitate the oversight of the Islamic education and upbringing of the children under kafala and also to take care that these children remain under kafala. ${ }^{109}$ As to the last point, it is interesting to remark that the initial measure, to bring to a halt the practice of the adoption of children of prohibitive status, would soon be consolidated in a formal provision against the adoption of children of prohibitive status with the enactment of a PIL ban. ${ }^{110}$

54. Such regulation exists in article 370-3 (2) FCC since 2001. The French scholarship was quick to see the message sent out to the foreign authorities: these should rest assured that French citizens cannot flout them by concealing their ulterior motive, which is no other than the adoption of the child once they are on French soil -adoption is not possible! ${ }^{111}$ Granted, it may become possible after 3 years, when the child has the right to become French citizen (see article 21-12 no 1 FCC). ${ }^{12}$ However, this change of tack is the result of a change of conditions and is not understood any differently by the foreign authorities. Of the essence for them is that French law has not ignored their position. ${ }^{113}$

55. As the PIL ban on adoption contributes to the sustainability of inter-country kafala, it secures, in behalf of all potential users of the institution, the opportunity to rely on it to build a family life in France. Both Muslim minors who will need a family and adults who will be available to offer this family are concerned ${ }^{114}$ and, in substance, it is into the interests of each of these indeterminate individuals that the 'public interest' or 'general interest of the community' invoked in Harroudj breaks down.

\section{B) The Islamic state's sovereignty}

56. The PIL ban on adoption makes sense irrespective of any practical effect awaited from its enforcement. This is because it pursues a noble purpose -it is the product of the decision "to reject any "imperialistic" and [...] indeed sometimes "colonialist" reading of the French law, that would postulate [its] superiority [...] over the other legal systems, judged to be by nature less favourable to the child'. ${ }^{115}$

\footnotetext{
${ }^{109}$ See N. Marchal Escalona, "Problèmes actuels de reconnaissance de la kafala marocaine auprès des autorités espagnoles", Paix et Securité Internationales, 4, 2016, pp. 197 et seq., especially p. 200 (available at https://dialnet.unirioja.es/ servlet/articulo?codigo $=5801826$ accessed on 24 September 2020 ).

${ }^{110}$ See article 3.20 of law no 26/2015 of 28th of July 'on amendment of the protection system for childhood and adolescence', adding a section 4 to article 19 of law no 54/2007 of 28th December 2007 'on International Adoption'. This reads:

'In the case of children whose national law prohibits or does not provide for adoption, the granting of adoption shall be refused unless the child is in a situation of distress and is a ward of the Public Entity.'

It is worth noting that such rule was incorporated in the first draft of the text, but was later on eliminated, although by then (2007) Morocco had already on several occasions discontinued the intear-country kafala [E. RodRíguez PINEAU, "La protección en España de menores cuya ley nacional prohíbe la adopción tras la reforma de la Ley 54/2007, de Adopción Internacional", Derecho Privado y Constitución, 31, 2017, pp. 387 et seq., especially p. 407 (available at https://dialnet.unirioja.es/servlet/articulo?codigo=6248746 accessed on 24 September 2020); also, M. Del Pilar Diago Diago, "Denegación de constitución de Kafala por parte de extranjeros que no residen habitualmente en Marruecos. Circular no 40 S/2 Reino de Marruecos" (available at http:// www.millenniumdipr.com/e-68-5-n\%C2\%BA-2-denegacion-deconstitucion-de-kafala-por-parte-de-extranjeros-que-no-residenhabitualmente-en-marruecos-circular-n\%C2\%BA-40-s-2-reino-demarruecos accessed on 24 September 2020)].

${ }^{111}$ B. Bourdelors, "L'adoption internationale", in Droit international privé : travaux du Comité français de droit international privé, 15e année, 2000-2002, Paris, Éditions Pedone, 2004, pp. 139 et seq., especially p. 152 (available at https://www. persee.fr/issue/tcfdi_1140-5082_2004_num_15_2000 accessed on 24 September 2020).

${ }^{112}$ See supra at II.3.

${ }^{113}$ Thus, they have no reason to 'suddenly close the valves' and not let 'get out a single child' (see in these terms J. FoYER, in the discussion following the submission of B. Bourdelois, supra n. 111, p. 173; similarly, H. Fulchiron, supra n. 37, p. 817).

${ }^{114}$ See also H. Fulchiron, supra n. 37, p. 817.

${ }^{115}$ Intervention of N. Borvo during the French Senate's debates of 10 January 2001 on the bill concerning international adoption (available at http://www.senat.fr/seances/s200101/s20010110/sc20010110015.html accessed on 24 September 2020).
} 
In this respect, whether the danger of backlash is allowed for or not, self-restraint is recommended as a matter of principle. ${ }^{116}$

57. The ECtHR touches upon this dimension when it praises France in that, by not 'cutting [...] off [children of foreign origin] immediately from the rules of their country of origin, [it] has shown respect for cultural pluralism [...]'. ${ }^{117}$ Some hold this reference as equivalent to respect for 'the individual's cultural identity'. ${ }^{118}$ However, as already said, the individual's cultural identity is an amalgam containing a weaker national component (which is contra adoption) plus a stronger French component (which is pro adoption), and article 370-3 (2) FCC does not reflect this make-up when it accommodates the national in place of the French part of the cultural identity. ${ }^{119}$ Indeed, if an interest is promoted by article 370-3 (2) FCC, this cannot be the minor's interest to refer to her law of origin and, through this medium, to her family and social memory (her parents are unknown and also her displacement occurred when she was only three months old), but it is the other way around, namely it is the interest of the law of origin to fix the minor's personal status although no real ties with the birthplace exist -the birth in this place counts instead of anything else.

58. Looked at from this standpoint, article 370-3 (2) FCC -at least on its face- seems to be attracted by a north-American neo-statutist logic advocating the regulation of the conflict of laws on the basis of the 'compelling governmental interests' at stake, as H. MuIR WATT observes ${ }^{120}$, stressing, however, that in this framework the 'compelling governmental interests' are not merely dictated by the will of the state to bring a case under its law, but also, mainly, depend on an objective assessment of the quality and intensity of the factual connection of this law with this case. ${ }^{121}$ Such an assessment is missing from the said norm. This applies uniformly on children non-abandoned or abandoned in the country of origin and on children having spent in the country of origin before their arrival in France a remarkable or a negligible part of their lifetime. Which means that these factors are irrelevant ${ }^{122}$ and the prohibition of the country of origin is called upon to govern adoption by virtue of unqualified, self-asserting 'compelling governmental interests', approved by the forum for no other reason than pure international comity: respect to foreign sovereignty.

\section{Proportionality of the PIL ban on adoption}

59. The ECtHR finds no violation of article 8 ECHR by the PIL ban on adoption, holding that the respondent state 'has struck a fair balance between the public interest and that of the applicant' ${ }^{123}$

60. The ECtHR observes that the respondent state 'has put in place a flexible arrangement', as it 'provides the means to alleviate the effects of that prohibition': first, the ban is immediately 'set aside' if the place of birth and habitual residence of the child is France; second, the ban is 'gradually' 'circumvented

${ }^{116}$ In this spirit J. Foyer, supra n. 113, p. 173; H. Fulchiron, supra n. 37, p. 817; also, B. Bourdelois, supra n. 111, p. 150: French law is laid down with 'clear conscience'.

${ }^{117}$ Harroudj, § 51 .

${ }^{118}$ H. vAN LOON, "Ensuring continuity of personal status and family relations across borders: the interaction between private international law and human rights", in H. Muir Watt, L. Bíziková, A. Brandẽo de Oliveira and D.P. Fernández Arroyo (eds.), Global Private International Law: Adjudication Without Frontiers, Cheltenham, Gloss, UK / Northampton, Massachusetts, USA, Elgar Publishing, 2019, pp. 530 et seq., especially p. 536; P. KInsch, "Harroudj v. France: Indications from the European Court of Human Rights on the Nature of Choice of Law Rules and their Potentially Discriminatory Effect", Yearbook of Private International Law, 15, 2013/2014, pp. 39 et seq., especially p. 43.

${ }^{119}$ See supra at IV.1.C).

${ }^{120}$ H. MuIR WATt, supra n. 91, pp. 1005, 1008.

${ }^{121}$ Ibid, pp. 1008-1009; also, S. SymeONIDES, "Revolution and Counter-Revolution in American Conflicts Law: Is There a Middle Ground?", Ohio State Law Journal, 46, 1985, pp. 549 et seq., especially p. 556 (available at https://kb.osu.edu/bitstream/handle/1811/64275/OSLJ_V46N3_0549.pdf?sequence=1\&isAllowed=y accessed on 24 September 2020).

${ }^{122}$ H. Muir Watt, supra n. 91, p. 1009.

${ }^{123}$ Harroudj, § 51 . 
by the possibility for the child to get French nationality, within a reduced period of time'. ${ }^{124}$ Undoubtedly, the ban admits relaxation. However, the system cannot be assessed as 'overall balanced' because it somehow satisfies the public interest (with the ban) as well as the private interest (with the relaxation). The issue is whether the system is balanced in the cases falling under the ban. The affirmative requires sufficient support of the view that the public interest outweighs the private interest, taking into account the margin of appreciation that the respondent state may have in the determination of the 'relation of precedence'. ${ }^{125}$

\section{Margin of appreciation $v$ 'precedent'}

61. The ECtHR has normally relied on its past decisions,

except where cogent reasons impelled it to adjust the interpretation of the Convention to changes in societal values or in present-day conditions. [...] It is indeed in the interests of legal certainty, of a coherent development of the Convention case-law, of equality before the law, of the rule of law, and of the separation of powers for the Court to follow in principle a moderated doctrine of precedent. ${ }^{126}$

62. In Wagner, ${ }^{127}$ the ECtHR had to deal with the refusal of the Luxembourg authorities to grant exequatur of an adoption issued in Peru. Luxembourg was condemned -inter alia- for violation of the right to family life of the two applicants, the adoptive mother and the adopted daughter, who were considered being such only in Peru. ${ }^{128}$ Arguably, Wagner is not irrelevant to Harroudj and Chbihi as far as these two concern the refusal of the authorities in France and Belgium, respectively, to pronounce the adoption of makfouls by their kafils. The result is common in all cases: persons cannot connect with parentage based on adoption because the forum does not provide necessary legal means to work this out. Therefore, the question is whether Wagner sets a precedent for Harroudj and Chbihi, so that France and Belgium should not possess the margin of appreciation that the ECtHR eventually accorded them. ${ }^{129}$

63. In the view of the ECtHR, Harroudj and Chbihi are to be distinguished from Wagner. ${ }^{130}$ Admittedly, nowhere is adoptive parentage possible. However, the problem for the parties varies: in Wagner, they have related with adoption abroad and what they are denied is adoption's recognition in Luxembourg; in Harroudj and Chbihi, they have not related with adoption abroad, but what they are denied is adoption's constitution in France and Belgium. On the one hand, they cannot enjoy an acquired status. On the other hand, they cannot accede to a new status. ${ }^{131}$ This difference is not just about a mere technicality. It directly influences the balancing in the cases under discussion. If the right of article 8 ECHR drives the request both for the exequatur of the decision of adoption (in Wagner) and the pronouncement of adoption (in Harroudj and Chbihi), it does not carry the same weight in both contexts. This is because only in the first does this take the form of a vested right to the requested status, a quality that brings greater pressure to bear on the forum for the protection of family life. ${ }^{132}$

${ }^{124} \mathrm{Ibid}, \S 51$.

${ }^{125}$ On this see R. Alexy, supra n. 31, pp. 50-56 (Präferenzrelation).

${ }^{126}$ L. WILDHABER, "The European Court of Human Rights: the Past, the Present, the Future", American University International Law Review, 22, 2007, pp. 521 et seq., especially pp. 524-525 (available at https://digitalcommons.wcl.american.edu/ cgi/viewcontent.cgi?article $=1128 \&$ context=auilr accessed on 24 September 2020).

${ }^{127}$ Wagner, supra n. 55.

${ }^{128}$ As a matter of fact, the parties stated at the hearing before the ECtHR that, in the meantime, they had had a simple adoption established in Luxembourg, which, however, 'did not take into account of the full adoption' established Peru (ibid, § 40).

${ }^{129}$ Harroudj, §§ 48, 52; Chbihi, §§ 92, 128, 130.

${ }^{130}$ Harroudj, § 47; Chbihi, § 91.

${ }^{131}$ On this point see also P. HAmmje, supra n. 75, p. 2951, no 17 ('discontinuité'); S. Bollée, supra n. 88, p. 721 ('rupture').

${ }^{132}$ Cf. P. HAMmJE, supra n. 75, p. 2948, no 6 (adding that there must also be a 'legitimate expectation' of the stability of the vested right [whether or not this extra element is correctly ascertained in Wagner ( $\S 130,155)$ will not be discussed here)]. Wagner emphasises that 'the social reality of the situation' had been overlooked $(\S \S 132,133)$. However, one should not 'read more $[\ldots]$ in the expression [...] than it says' by isolating it from the rest of the judgment (as cautioned by H. vAN LoON, supra n. 118, p. 534). This happens when it is maintained that de facto family life and its "“cristallisation" [...] through the passage 
64. That said, the approach of Wagner remains pertinent as regards the deployment of effects proper to kafala, since this is the status validly created abroad that should apply undisturbed in the host country where the kafils with the makfouls have subsequently moved. ${ }^{133}$

\section{Margin of appreciation - scope}

65. Where exactly the margin of appreciation ends and the European supervision begins is a question with no single definitive answer. The ECtHR employs 'a sliding scale model', according to which the margin of appreciation may range from very broad to very narrow and the level of scrutiny may range from very light to very strict, respectively, while intermediate states between the two extremes are imaginable. ${ }^{134}$ Starting from the assumption that the transformation of the kafala into adoption concerns obligations (and rights) for positive state action and contrasting these to the obligations (and rights) for negative state action, the ECtHR goes on to make two contradictory general statements in Harroudj and Chbihi. In the first, it holds that 'the margin of appreciation [...] may be wider than that applied in other areas under the Convention. ${ }^{135}$ In the second, it holds that 'the applicable principles are comparable' so that in all areas under the Convention 'a certain margin of appreciation' is operative. ${ }^{136}$ Both these statements lack precision. Contrary to the second, the boundaries of discretion are not identical in the two sets of obligations, in the sense that a greater discretion exists in obligations for positive action than in obligations for negative action. Contrary to the first, the extra room for manoeuvre is verifiable only in one specific field, in connection to 'means-selecting discretion', ${ }^{137}$ as all other kinds of discretion are present in the framework of negative and positive obligations alike. ${ }^{138}$ The exception stems from a fundamental difference in the structure of the obligations. Negative obligations have a

of time' is in substance the necessary and sufficient condition of the judgment, which 'would [...] have probably been similar' as long as mere de facto family life existed [D. SINDRES, "'Foreign situations' and conflict of laws: thinking outside-the-box approach to private international law", in H. Muir Watt, L. Bíziková, A. Brandão de Oliveira and D.P. Fernández Arroyo (eds.), Global Private International Law: Adjudication Without Frontiers, Cheltenham, Gloss, UK / Northampton, Massachusetts, USA, Elgar Publishing, 2019, pp. 538 et seq., especially p. 540]. Harroudj and Chbihi defeat this contention: here, mere de facto family life of the kafils with the makfouls proves impotent to curb the resistance with which adoption is met by the forum.

${ }^{133}$ This issue is not resolved if kafala is compressed to fit into an inadequate institution of the host country. For example, according to the prevailing opinion in France, the responsibility of the kafil to take decisions about the person and the patrimony of the makfoul cannot be subsumed under the 'autorite parentale', but must be paralleled either to a 'delegation parentale' (institution designed only for one délégataire and thus not-reflective of a kafala accorded to couples; A. GouTTENOIRE AND M. Lamarche, "Recherche d'équivalent : 1'autorité parentale", Droit de la Famille - Revue Mensuelle LexisNexis Jurisclasseur, 2009, pp. 42 et seq., especially p. 46; Y.A. Roblen, supra n. 35, p. 327) or to a 'tutelle' (institution burdened with formalities alien to kafala; J.-M. PLAZY, "Une recherche d'équivalent : la tutelle", Droit de la Famille - Revue Mensuelle LexisNexis Jurisclasseur, 2009, pp. 48 et seq., especially pp. 49, 50; Y.A. RовLEH, supra n. 35, p. 332). In this way, kafils and makfouls are deprived, to a greater or lesser extent, of their status validly created abroad, owing to the 'partial recognition' of the kafala [which is a partial recognition for the reasons exposed, and not because the adoption is ruled out (as implied by L.R. KIESTRA, The Impact of the European Convention on Human Rights on Private International Law, The Hague, The Netherlands, Springer, 2014, pp. 231, 233, 244, 299, 303), as if the adoption were part and parcel of the kafala!].

134 J. Gerards, "Pluralism, Deference and the Margin of Appreciation Doctrine", European Law Journal, 17, 2011, pp. 80 et seq., especially pp. 105-106; also, B. Rainey, E. Wicks And C. Ovey, Jacobs, White, and Ovey: The European Convention on Human Rights, New York, USA, OUP, 7th edn., 2017, p. 360; L. LAVrYsen, supra n. 70, p. 328.

${ }^{135}$ Harroudj, $\S 47$.

${ }^{136}$ Chbihi, § 92 .

${ }^{137}$ On this see R. Alexy, supra n. 31, p. 396.

${ }^{138}$ R. AleXY, supra n. 31 draws an important distinction between structural and epistemic discretion. In structural discretion (pp. 393, 394-414) the legislature is free to choose because the constitution (here, the ECHR) neither commands nor prohibits an action or omission, so that either the action or the omission is legally permitted. This situation may play out on separate levels and give rise to: (i) end-setting discretion; (ii) means-selecting discretion; and (iii) discretion in balancing. In epistemic discretion (pp. 393, 414-425) the legislature is free to choose, as it is not known whether the constitution (here, the ECHR) either commands or prohibits or neither commands nor prohibits something because of deficiencies in relevant empirical or normative knowledge. The above forms of discretion -apart from (ii)- are not peculiar to the field of positive obligations, although they are more frequent and even sometimes more complex here than they are in the field of negative obligations, which 'amounts to a difference of degree' (pp. 314, 312). 
conjunctive structure -for example, the prohibition of killing implies a prohibition of every possible act of killing. But positive obligations have a disjunctive structure -for example, the command to rescue is not a command to carry out every possible act of rescue simultaneously; if the result may be achieved by various means, what is required is the performance of either $M_{1}$, or $M_{2}\left(\right.$ or $M_{3} \ldots$ or $\left.M_{\mathrm{n}}\right)$, and thus the addressee of the command has means-selecting discretion. ${ }^{139}$

66. In any event, means-selecting discretion presupposes a plurality of 'equally suitable' means, ${ }^{140}$ which is not the case in Harroudj and Chbihi. Here, although the right to family life is better served with adoption rather than with kafala, kafala is preferred to adoption. This cannot be the outcome of means-selecting discretion availed to the French and Belgian legislature and must be explained otherwise.

\section{Margin of appreciation - type: empirical and normative}

67. If the legislature is at liberty to put kafala before adoption, this is not because the public interest can be assessed as more important than the right to family life, nor is it because the public interest and the right to family life can be assessed as equally important, in which cases the legislature would have structural discretion to lean towards the public interest. ${ }^{141}$ These assessments seem unsafe, as no sound empirical or normative knowledge can be adduced to substantiate them. Under such conditions, the legislature may still take a decision to the detriment of the human right, thanks to knowledge-related or epistemic discretion, ${ }^{142}$ despite the risk that the decision 'may be false' in the sense that ' $[\mathrm{h}]$ itherto unperformed empirical investigations or hitherto unconsidered normative arguments may make the mistake apparent. ${ }^{143}$ This discretion is further divided into two subcategories, depending on whether we are facing empirical or normative uncertainty: uncertainty about empirical premisses gives rise to empirical epistemic discretion; uncertainty about normative premisses gives rise to normative epistemic discretion. ${ }^{144}$ As it will be shown below, each of these subcategories of discretion undergirds a distinct consideration of the public interest, i.e. empirical discretion couples with the Islamic backlash hypothesis, whereas normative discretion couples with the Islamic sovereignty thesis. ${ }^{145}$

\section{The backlash hypothesis and the legislature's leeway for empirical assessment}

68. The proportionality (stricto sensu) of the restriction of adoption set in article 370-3 (2) FCC is not doubtful, on the assumption that any other option would provoke the resentment of the Islamic states and, as a corollary, the termination of inter-country kafala. In such a case, a conflict of rights ari-

${ }^{139}$ R. Alexy, “On Constitutional Rights to Protection”, Legisprudence, 3:1, 2009, pp. 1 et seq., especially pp. 5, 16; also, M. KLATt, "Positive Obligations under the European Convention on Human Rights", Zeitschrift für ausländisches öffentliches Recht und Völkerrecht (ZaöRV), 71, 2011, pp. 691 et seq., especially pp. 694-695, 715-716 (available at https://www.zaoerv. de/71_2011/71_2011_4_a_691_718.pdf accessed on 24 September 2020).

${ }^{140}$ R. Alexy, supra n. 31, p. 396.

${ }^{141}$ On structural discretion see supra $\mathrm{n} .138$. Why the legislature would have structural discretion also in the first case, in which the public interest would weigh heavier than the right of article 8 ECHR, needs clarification. The reason is that the public interest is an 'optimisation permission' rather than an 'optimisation requirement' (J. Rivers, "Proportionality, Discretion and the Second Law of Balancing", in G. Pavlakos (ed.), Law, Rights and Discourse. The Legal Philosophy of Robert Alexy, Oxford and Portland, Oregon, Hart Publishing, 2007, pp. 167 et seq., especially p. 168), so that the legislature may choose whether it wants to promote this interest instead of the human right or whether it wants to promote the human right instead of this interest. We are here in the realm of structural -in particular, of end-setting-discretion (R. ALEXY, supra n. 31, p. 395).

${ }^{142}$ On epistemic discretion see supra at n. 138.

${ }^{143}$ R. AleXY, supra n. 31, pp. 416, 422.

${ }^{144}$ Ibid, pp. 393, 414-415.

${ }^{145}$ On the worry about the Islamic backlash see supra at IV.2.A). On the respect of the Islamic sovereignty see supra at IV.2.B) 
ses. In favour of the restriction are the rights of all those who would suffer harm after the taking of the retaliatory measure (say, group A); this harm is prevented with the restriction. Against the restriction are the rights of all those who would have made it to draw benefit before the taking of the retaliatory measure (say, group B); this benefit is waived with the restriction. Now, the rights of group A are weightier than the rights of group B. Why? First, the rights of A outnumber the rights of B, since A and B contain instances occurring within unlimited ${ }^{146}$ and limited ${ }^{147}$ timeframes, respectively. Second, the harm for each instance in A exceeds the benefit for each instance in B. Surely, there is much harm for an adult and a minor (in A) if these are excluded from inter-country kafala that could have brought them together. The whole prospect of common family life is frustrated and the status quo is maintained, which is, for childless adults and parentless minors, particularly unwelcome. On the contrary, there is little or at most a moderate benefit for an adult and a minor (in B) to transition from kafala to adoption. What it is all about here is the mere promotion of the existing family life even sooner than when this becomes possible under the current regime anyway (see article 21-12 no 1 FCC). If we multiply the two figures, the numerical difference of A as compared to B with the difference of the degree of injury sustained in $\mathrm{A}$ as compared to $\mathrm{B}$, then, as a result, we have the precise (fairly big) difference of value of the rights of $\mathrm{A}$ against the rights of $\mathrm{B}$ emerging in balancing. No uncertainty on the normative level remains.

69. On the other hand, this balancing is predicated on an assumption that is itself dubious. By claiming that, if it were not for the PIL ban on adoption, a diplomatic red line would be crossed and the termination of inter-country kafala would take place, one ventures a prognosis on the future course of events. ${ }^{148}$ Not everyone finds the prognosis likely. ${ }^{149}$ However, the prognosis falls within the discretion of the legislature. This is not to say that the legislature has carte blanche to go for the PIL ban on adoption irrespective of the extent of the restriction to the rights of group B and the probability of realisation of the rights of group A via the restriction. Rather, the rule holds that the more extensive the restriction to the rights of $\mathrm{B}$ is, the more probable must be the realisation of the rights of A via the restriction. ${ }^{150}$ Such rule is not an issue in this case. Since no serious cost is inflicted to B, the standards of review of the expectation of gain for A are debased accordingly, namely no 'intensive review of content' (that the expectation is 'reliable') is required, but a 'plausibility review' (that the expectation is 'plausible'), if not a mere 'evidential review' (that the expectation is not 'evidently false'), suffices. ${ }^{151}$ The PIL ban on adoption passes muster.

70. This 'prognostic discretion' 152 covers both the two first limbs of the proportionality test; it attests that the PIL ban on adoption is not only suitable but also necessary to avoid the discussed reaction because there are no alternative means with less cost for the rights of group $\mathrm{B}$, capable of reaching an equally positive outcome for the rights of group A. ${ }^{153}$ It has been suggested that the problem of fraud to Islamic law -where the root of evil lies- should be subject to examination by the court on a case-by-case basis. Each time adoption would be pursued as soon as the kafil with the makfoul set foot in France, the question should be whether this is a 'deliberate displacement', in the sense that the kafala was nothing but a pretense to get permission to travel with a view to the adoption in France, or not. ${ }^{154}$ The negative answer may be appropriate in special cases. ${ }^{155}$ However, as it is conceded, intentions are often obscure

\footnotetext{
${ }^{146}$ The assumption does not insinuate that at some point the retaliation measure would be reversed.

147 The assumption is that at some point a retaliation measure would be taken.

${ }^{148}$ R. Alexy, supra n. 31, p. 310.

${ }^{149}$ In Harroudj, § 34, the applicant questions the prognosis.

${ }^{150}$ R. AleXY, supra n. 31, pp. 313, 418-420 ('second Law of Balancing').

${ }^{151}$ On this scale of review see ibid, pp. 313, 419, 420.

${ }^{152}$ Ibid, pp. 313, 314.

${ }^{153}$ On the role of epistemic discretion in examining suitability and necessity see ibid, pp. 399, 400, 414.

${ }^{154} \mathrm{H}$. Muir WATt, "Vers l'inadoptabilité de l'enfant étranger de statut personnel prohibitif? À propos de la circulaire du 16 février 1999 relative à l'adoption internationale”, Revue critique de droit international privé, 88, 1999, pp. 469 et seq., especially pp. 486-490.

${ }^{155}$ Ibid, p. 491.
} 
and it may be 'extremely delicate' to separate good from bad faith, the wheat from the chaff. ${ }^{156}$ As a consequence, the door is left ajar for abuses. ${ }^{157}$ Correspondingly, the risk of the reaction can still appear too high (for the interests of A) and not worth taking (for the interests of B) in the eyes of the legislature.

\section{The sovereignty thesis and the legislature's leeway for normative assessment}

71. Our ignorance on whether the restriction of the right to family life by the PIL ban on adoption is justified or not does not disappear when we change perspective and try to associate it with the requirement of respect towards the Islamic prohibition of tabanni, as a form of 'respect for cultural pluralism' that boils down to 'respect to foreign sovereignty'. However, a difference exists with the previous situation, in which the factual background of the suitability and the necessity was blurry, whereas the best weighting of the competing interests was plain. Here, it is the exact opposite. What is sure is that the restriction of the human right yields optimal respect for the Islamic law. This judgment is not dependent on the anticipation of any sequence of events and the relevant calculation of probabilities. It is valid on logical grounds. But the problem is elsewhere. What is not sure is whereon the restriction of the human right for purposes of respect of the Islamic law stands. This judgment implies a scale of classification of the degree of non-satisfaction of the human right (let's symbolise this with $R$-, where the minus denotes the value of non-satisfaction of the right $(R))$ and the degree of importance of the respect to cultural pluralism and foreign sovereignty (let's symbolise this with $P S+$, where the plus denotes the value of importance of pluralism and sovereignty $(P S)$ ), upon which rests the ranking of the objects of evaluation.

If we use a three-point scale of light $(l)$, moderate $(m)$ and serious $(s)$ for the theoretically possible non-satisfaction (-) of $R$ and importance (+) of $P S,{ }^{158}$ the following observations apply:

The PIL restriction will be considered proportionate if $P S+$ ranks higher than $R$ - [the circumstances for this are: (1) $P S+: s / R-: l$; or (2) $P S+: s / R-: m$; or (3) $P S+: m / R-: l]$, or if $P S+$ ranks on a par with $R$ - [the circumstances for this are: (4) $P S+: l / R-: l$; or (5) $P S+: m / R-: m$; or (6) $P S+$ $: s / R-: s]$. Under such circumstances, $P S$ may take precedence over $R .{ }^{159}$

The PIL restriction will be considered disproportionate if $R$ - ranks higher than $P S+$ [the circumstances for this are: (7) $R-: s / P S+: l$; or (8) $R-: s / P S+: m$; or (9) $R-: m / P S+: l]$. Under such circumstances, $R$ must take precedence over $P S$.

Admittedly, not everything in this table is realistic, as some circumstances are excluded from the outset. This is true for (6), (7) and (8), since adoption with a 'slight delay' 160 is not a 'serious' offence to $R$. For sure, $R-: s$ is a non-starter. This practically leaves us, on the one hand, with each possibility from (1) to (5) and, on the other hand, with the possibility under (9). How can we tell the truth of the matter? Obviously, we cannot, and this brings to the fore the normative discretion of the legislature to resolve the conflict either way. The choice the legislature has come up with is to assign values that lead to one of the combinations from (1) to (5) to accommodate Islamic law. ${ }^{161}$

\footnotetext{
${ }^{156}$ Ibid, p. 491.

${ }^{157}$ P. LAGARde, "La loi du 6 février 2001 relative à l'adoption internationale : une opportune clarification”, Revue critique de droit international privé, 90, 2001, pp. 275 et seq., especially p. 287.

${ }^{158}$ On this triadic model see R. AlEXY, supra n. 31, pp. 402-412. The scale could, of course, be more refined (p. 412: ninepoint scale), but no such need appears for us here [after all, there are limits in the quest for precision: as the divisions of the system increase, this quickly loses its heuristic value, becoming unworkable and incomprehensible (pp. 412-413)].

${ }^{159}$ Thanks to structural discretion: see supra n. 138 and n. 141.

${ }^{160}$ P. LAGARDE, supra n. 157 , p. 288 ('léger retard').

${ }^{161}$ This normative discretion may be termed 'cultural discretion'(J. RIVERS, supra n. 141, pp. 178-180; Id., Proportionality and Discretion in International and European law, in N. TSAGOURIAS (ed.), Transnational Constitutionalism. International and European Models, New York, USA, CUP, 2007, pp. 107 et seq., especially 118-119) or, perhaps more accurately, 'multicultural discretion', a sub-type denoting freedom of the legislature to raise against the human right cultural (moral, religious) objections that do not come from affected standards and conceptions of good prevalent in the domestic cultural system, but pertain directly to another cultural system, which is recognised on account of 'cultural openness'.
} 
72. However, this analysis is still incomplete and does not necessarily establish a margin of appreciation to neglect the ECHR right. Normally, the margin depends on the absence of a sufficient consensus suggesting that the ECHR right deserves protection, to the effect that the margin shrinks as consensus grows and some 'tipping point' in this equation exists at which the margin may be upset by consensus. ${ }^{162}$ Therefore, the next thing to look into is whether this condition is satisfied. The question is as follows: is the PIL ban on adoption open to challenge on grounds of adoption-friendly consensus, connoted in materials of comparative law or international law? ${ }^{163}$ Is there such a margin-breaking consensus?

\section{Margin-breaking consensus in comparative law?}

73. To reach its judgment, the ECtHR has recourse to a comparative study conducted in twentytwo member states where a significant if not the greater part of the population is Muslim. ${ }^{164}$ From the information gathered, it turns out that in none of these is kafala considered as adoption ${ }^{165}$ and, further, that their 'choice-of-law rules in matters of adoption tend to vary'. ${ }^{166}$ Based on the last point, the ECtHR notes that:

There is no clear measure of common ground between the member States [...]. Consequently, the margin of appreciation afforded to the French authorities should be regarded as broad. ${ }^{167}$

74. This finding is subject to criticism. Unfortunately, its focus is not where it should be, namely on the ensemble of states that allow the Islamic law to put an obstacle to adoption, but do not enshrine a PIL restriction of the same intensity as article 370-3 (2) FCC does. Two approaches can be discerned within this ensemble. On the one hand, we have states that give preference to the adoptee's or the adopter's national law, or to the national law of the adoptee and of the adopter cumulatively, ${ }^{168}$ which means that they may be called to implement the Islamic law as lex causae. This will happen provided that the Islamic law keeps with the international public order of the forum. ${ }^{169}$ On the other hand, we have

${ }^{162}$ On this correlation of margin and consensus see early on The Sunday Times $v$ The United Kingdom, no 6538/74, 26 April 1979, § 59; also, with references to subsequent ECtHR case law, e.g. J. GERARDS, supra n. 134, pp. 107, 108-110; K. DzEHTSIARou, European Consensus and the Legitimacy of the European Court of Human Rights, Cambridge, UK, CUP, 2015, pp. 132-142; F. DE Londras And K. Dzehtsiarou, Great Debates on the European Convention on Human Rights, London, UK, Palgrave, 2018, pp. 111-112; Y. ARAI-TAKAHASHI, "The margin of appreciation doctrine: a theoretical analysis of Strasbourg's variable geometry”, in A. Føllesdal, B. Peters and G. Ulfstein (eds.), Constituting Europe. The European Court of Human Rights in a National, European and Global Context, New York, USA, CUP, 2013, pp. 62 et seq., especially pp. 87-89.

${ }^{163}$ On these two sources of consensus see J. Gerards, supra n. 134, p. 109 and, extensively, K. Dzehtsiarou, supra n. 162, pp. 39-49; F. DE LONDRAS AND K. DzehtSiarou, supra n. 162, pp. 79-85.

${ }^{164}$ Harroudj, $\$ 21$.

${ }^{165} \mathrm{Ibid}, \S 21$.

${ }^{166} \mathrm{Ibid}, \S 22$.

${ }^{167} \mathrm{Ibid}, \S 48$.

${ }^{168} \mathrm{Ibid}, \S 22$.

${ }^{169}$ See, characteristically, OLG Karlsruhe, 25.11.1996, Praxis des Internationalen Privat- und Verfahrensrechts (IPRax), 1,1999 , pp. 49 et seq. (with comment by E. JAYME), upholding an appeal against the decisions of lower courts (AG and LG Heidelberg) that had rejected a request for adoption of a Moroccan child by a German-Moroccan couple merely because, according to article $22 \mathrm{EBGB}$, the issue was governed by Moroccan law. This is insufficient to support the application of the Islamic prohibition. What is further required is to make sure that the application of the Islamic prohibition does not come into 'unbearable contradiction with fundamental principles of German law', in which case it falls on the 'fire-wall' of the German international public order (article 6 EBGB). The problem occurs if the situation at hand presents an appropriate measure of Inhandsbezug (because, for example, the family has its permanent residence in Germany and there is no intention of return to Morocco), while the best interest of the child is also well-served through the adoption. As far as the last point is concerned, even though the counteracting imperative for 'continuity of the cultural identity' of the child should not be understated, there may be other dominant considerations in favour of the adoption [even the full adoption, enshrined in $\S \S 1741$ et seq. BGB: see comment by E. JAYME, p. 50; A. ColOMBI CIACCHI, Internationales Privatrecht, ordre public européen und Europäische Grundrechte (Zentrum für Europäische Rechtspolitik an der Universität Bremen (ZERP)-Diskussionspapier 1/2008, 2009), pp. 26-30 (available at https://www.ssoar.info/ssoar/handle/document/62589 accessed on 24 September 2020); contra: K. KLINGENSTEIN, Kulturelle Identität und Kindeswohl im deutschen internationalen Adoptionsrecht, Frankfurt am Main, Peter Lang, 2000 , pp. 112, 113, maintaining that $\S \S 1741$ et seq. BGB are not part of the German international public order]. 
states that 'show a certain reticence towards the adoption' if the adoption is prohibited in the country of origin of the child, 'for example, by imposing additional conditions in such cases' ${ }^{170}$ and, above all, a strict procedure of cooperation with the competent authorities of the country of origin of the child. ${ }^{171}$ Therefore, in both groups, adoption is possible even during the waiting period that the French law observes categorically (see article 21-12 no 1 FCC). In this respect, the French law is lagging behind the majority of the restrictive states. Moreover, this discrepancy is presumably expanded once all the restrictive states of the Council of Europe are factored in, not only the selected twenty-two members, but also the rest of the twenty-five members that were left out from the outset, just because of the smaller percentage of Muslim element in their population composition, without explanation on how this renders their views on the issue indifferent and unworthy of being recorded. In sum, there is consensus for more freedom in adoption, it is robust and it flies in the face of the position of the ECtHR. ${ }^{172}$

75. However, it could be argued that, given the close relationship and the strong historical and political bonds entertained with the Maghreb countries, France is in a sensitive position, urging, perhaps, for a more generous negotiation with the Islamic law, despite European consensus. ${ }^{173}$

\section{Margin-breaking consensus in international law?}

76. The ECtHR holds that:

The Convention cannot be interpreted in a vacuum but must be interpreted in harmony with the general principles of international law. Account should be taken, as indicated in Article $31 \S 3$ (c) of the 1969 Vienna Convention on the Law of Treaties, of "any relevant rules of international law applicable in the relations between the parties", and in particular the rules concerning the international protection of human rights. ${ }^{174}$

77. Such an approach -i.e. to rely on external sources and refuse to consider 'the provisions of the Convention as the sole framework of reference for the interpretation of the rights and freedoms enshrined therein' ${ }^{175}$ - is sensible, since the ECHR forms part of the whole system of international law and therefore must be developed in a manner consistent with it. ${ }^{176}$ The international instruments explored in Harroudj are the United Nations Convention on the Rights of the Child of 20 November 1989 (hereinafter CRC), the Hague Convention of 29 May 1993 on Protection of Children and Co-operation in Respect of Intercountry Adoption (hereinafter HC 1993) and the Hague Convention of 19 October 1996

${ }^{170}$ Harroudj, § 22 .

${ }^{171} \mathrm{Ibid}, \S 22$, referring to article 365-1 of the Belgian Civil Code.

${ }^{172}$ Some scholars even argue that the consensus is unanimous, i.e. that France occupies a unique place in the European legal map, since no other state endorses an absolute prohibition of adoption [P. HAMmJE, supra n. 75, p. 2949, no 11; N. HeRvieU, supra n. 99; I. Gallala-ARndt, "Die Einwirkung der Europäischen Konvention für Menschenrechte auf das Internationale Privatrecht am Beispiel der Rezeption der Kafala in Europa. Besprechung der Entscheidung des EGMR Nr. 43631/09 vom 4.10.2012, Harroudj ./. Frankreich", Rabels Zeitschrift für ausländisches und internationales Privatrecht (RabelsZ), 79, 2015, pp. 405 et seq., especially 421, 426 (available at https://papers.ssrn.com/sol3/papers.cfm?abstract_id=2622998 accessed on 24 September 2020)]. This contention might have been accurate at the material time when Harroudj was adjudicated. However, since 2015, Spain has introduced similar legislation (on the Spanish PIL ban see supra n. 110). There is a difference with the French PIL ban, though: both are lifted with the acquisition by the foreign minor of the nationality of the state, after he remains for some time under the care of the foster parent-citizen of the state, yet this time is two years in Spain (see E. Rodríguez PINEAU, supra n. 110, p. 408) and three years in France. The PIL restriction is more tempered in Spain as compared with France.

${ }^{173}$ On the nature of European consensus as 'rebuttable presumption' see K. DzeHTSIARou, supra n. 162, pp. 3, 9, 27, 29, 30, 32-34; F. DE Londras and K. Dzehtsiarou, supra n. 162, pp. 82-83.

${ }^{174}$ Harroudj, § 42. See already the same statement in Neulinger and Shuruk v Switzerland, no 41615/07, 6 July 2010, § 131, with further references to similar previous case law going back to Golder $v$ The United Kingdom, no 4451/70, 21 February $1975, \S 29$.

${ }^{175}$ Demir and Baykara $v$ Turkey, no 34503/97, 12 November 2008, § 67.

${ }^{176}$ F. DE Londras and K. Dzehtsiarou, supra n. 162, p. 85. 
on Jurisdiction, Applicable Law, Recognition, Enforcement and Co-operation in Respect of Parental Responsibility and Measures for the Protection of Children. ${ }^{177}$ Remarkably, this overview does not point to an agreement pro libertate or even to a disagreement within the international community, but encounters a reverse consensus in favour of the French PIL ban on adoption, which is now justified 'largely on account of a concern to abide by the spirit and purpose of [the above] international conventions. ${ }^{178}$

78. The observations of the ECtHR will not be taken up in detail. By and large, they are not wellaimed and they rather distract attention from the crucial point of international consensus, which is no other than that contracting states to the CRC and the HC 1993 -the two conventions where the issue of adoption is raised-are not obliged to import adoption, be it domestic or international, into their legal orders. ${ }^{179}$

79. Provisions that highlight the non-prescriptive nature of adoption in general are articles 20 and 21 CRC. Under article 20, '[a] child temporarily or permanently deprived of his or her family environment or in whose own best interests cannot be allowed to remain in that environment, shall be entitled to special protection and assistance' (20 (1)) and 'States Parties shall [...] ensure alternative care [...]' (20 (2)). This 'alternative care' is to be decided 'in accordance with their national laws' (20 (2)) and 'could include [...] adoption [...]' (20 (3)). ${ }^{180}$ In the same vein, when article 21 lays down specific instructions concerning the aims and design of the 'system of adoption', it addresses these only to 'States Parties that recognize and/or permit the system of adoption'. The above formulations leave no doubt that we are here in the sphere of "what is possible [...] rather than [of] what is required'. ${ }^{181}$

80. Provisions that highlight the non-prescriptive nature of international adoption in particular are found in article 21(b) CRC and in the preamble to the HC 1993. Within this framework, international adoption 'may be considered as an alternative means of child's care' (article 21(b)) or 'may offer the advantage of a permanent family to a child' (preamble), which means, again, that it constitutes 'a potential response' to children without care and permanent family. ${ }^{182}$ Therefore, 'compliance with these treaties does not depend on carrying out such adoptions, either as a receiving country or as a country of origin. ${ }^{183}$

81. All in all, both the CRC and the HC 1993 delegate to the individual states the choice on how to proceed with adoption. The matter is in their hands. They may endorse adoption, domestic and international, in which case they are committed to implement article 21 CRC and the HC 1993; ${ }^{184}$ and they may move in the opposite direction to endorse the one and withhold the other form of adoption or even to withhold domestic and international adoption altogether. In this respect, it is notable that the international law leaves it open also for non-Islamic states to arrive at a position similar to the one that Islamic states are keen to take on religious grounds.

${ }^{177}$ Harroudj, $\S \S 18-20,49$.

${ }^{178} \mathrm{Ibid}, \S 50$. - Another rare example of 'restrictive interpretation' of the ECHR (article 5) based on international consensus (the Third and Fourth Geneva Conventions relating to detention) is Hassan v the United Kingdom, no 29750/09, 16 September 2014; see G. UlfSTEIN, "Evolutive Interpretation in the Light of Other International Instruments. Law and Legitimacy", in A. van Aaken and I. Motoc (eds.), The European Convention on Human Rights and General International Law, Oxford, UK, OUP, 2018, pp. 83 et seq., especially pp. 89-90, 91.

${ }^{179}$ See e.g. E. Bartholet, "International Adoption: Thoughts on the Human Rights Issues", Buffalo Human Rights Law Review, 13, 2007, pp. 151 et seq., especially (on CRC) p. 171 and (on HC 1993) pp. 170, 173 (available at https://digitalcommons. law.buffalo.edu/bhrlr/vol13/iss1/8/ accessed on 24 September 2020); N. CANTwELL, The Best Interests of the Child in Intercountry Adoption, Innocenti Insight, Florence: UNICEF Office of Research, 2014, pp. 31, 35 (available at https://www.unicefirc.org/publications/pdf/unicef\%20best\%20interest\%20document_web_re-supply.pdf accessed on 24 September 2020).

${ }^{180}$ Or, inter alia, kafala!

${ }^{181}$ N. CANTwEll, supra n. 179, p. 31.

${ }^{182}$ Ibid, p. 31.

${ }^{183} \mathrm{Ibid}$, p. 31 and further p. 35.

${ }^{184}$ Ibid, p. 35. 
82. If this stance can be validly construed as deference of the CRC and the HC 1993 to national sovereignty, ${ }^{185}$ then it is not possible to censure the French PIL ban on adoption for subscribing to the same principle fostered within the conventions!

\section{Concluding remarks}

83. The ECtHR is not very warm when considering claims regarding 'recognition' or 'facilitat[ion] of observance' of religious law. ${ }^{186}$ For example, the ECtHR absolves the impugned states of complaints lodged against them because they renounced to validate institutions such as religious marriage, ${ }^{187}$ or because they restricted freedom to manifestation of religious belief through the wearing of religious symbols and items of clothing -a restriction that may apply not only 'occasionally' during the taking of ID photos for use on official documents, or during security checks, but also invariably at school, at the university, at work, and in the public space. ${ }^{188}$ However, the kafala cases are nowhere in this list. ${ }^{189}$ Here, on the contrary, the impugned states align with religious law (the Islamic prohibition of adoption), whereas the individuals concerned oppose it and resort for relief to article 8 ECHR. In vain: the ECtHR does not find in their favour, judging that they may not escape the compulsory frame of religious law. ${ }^{190}$

84. As the analysis of Harroudj elucidated, the subordination to the Islamic prohibition of adoption rests on two pillars, one utilitarian (French law does not discard the prohibition out of worry about the prohibitive state's backlash) ${ }^{191}$ and another deontological (French law does not discard the prohibition out of respect of the prohibitive state's sovereignty). ${ }^{192}$ In this line of reasoning, it could be said that the 'receptiveness' of French law to Islamic law ranges from 'tolerance' to 'hospitality'. ${ }^{193}$ Tolerance is conditional acceptance of the foreign that 'also suggests disapproval' and 'sufferance [...] of otherness'. ${ }^{194}$ Hospitality is unconditional acceptance of the foreign, motivated by 'dialogic attitude towards difference'. ${ }^{195}$ Both these, the negative-more reserved and the positive-more willing mode of acceptance, ${ }^{196}$ inform the PIL ban on adoption and project as ingredients of its ambivalent ethical

${ }^{185}$ E. Bartholet, "The Debate (with D. Smolin)", in J. Gibbons and K. Smith Rotabi (eds.), Intercountry Adoption. Policies, Practices, and Outcomes, London / New York, Routledge, 2016, pp. 233, 234. However, on another view, state power to bypass adoption is not absolute; it is allowed only for the protection of the child's best interests (N. CANTWELL, supra n. 179, p. 31) in cases where necessary conditions -initially missing- must be put in place so that adoption is in line with the child's best interests [for example, such should be the policy underlying a moratorium on international adoption; ibid, pp. 3738; Permanent Bureau of the Hague Conference on Private International Law, The Implementation and Operation of the 1993 Intercountry Adoption Convention: Guide to Good Practice, UK, Family Law - Jordan Publishing, 2008, nos 457-461 (available at https://assets.hcch.net/docs/bb168262-1696-4e7f-acf3-fbbd85504af6.pdf accessed on 24 September 2020); S.V. BRAKMAn, "The Principle of Subsidiarity in the Hague Convention on Intercountry Adoption: A Philosophical Analysis", Ethics \& International Affairs, 33 (2), 2019, pp. 207 et seq., especially p. 224)].

${ }^{186}$ I. LeIGH, "Religious Adjudication and the European Convention on Human Rights", Oxford Journal of Law and Religion, 8, 2019, pp. 1 et seq., especially p. 9.

187 Şerife Yiğit v Turkey, no 3976/05, 2 November 2010.

${ }^{188}$ For a very quick overview of the ECtHR case law on the issue see ECtHR, Factsheet - Religious symbols and clothing, December 2018 (available at https://www.echr.coe.int/Documents/FS_Religious_Symbols_ENG.pdf accessed on 24 September 2020).

${ }^{189}$ Contra: I. Leigh, supra n. 186, p. 9 main text (on Chbihi) and at n. 47 (on Harroudj).

${ }^{190}$ Cf., on the other hand, Molla Sali v Greece, no 20452/14, 19 December 2018, in which non-consensual application of the Islamic law on the members of the minority of Western Thrace is frowned upon $(\S \S 156,157,160)$.

${ }^{191}$ See supra at IV.2.A).

192 See supra at IV.2.B)

${ }^{193}$ On the 'three possible degrees of receptiveness to the foreign', intolerance, tolerance and hospitality, see H. MUIR WATT, "Hospitality, Tolerance, and Exclusion in Legal Form: Private International Law and the Politics of Difference", Current Legal Problems, 70 (1), 2017, pp. 111 et seq., especially pp. 115, 116-125.

${ }^{194}$ Ibid, pp. 118-119.

${ }^{195} \mathrm{Ibid}$, p. 121. Hospitality 'allows the foreign on her own terms' (ibid, pp. 126, 135, 137, 138, 140). See further on this 'unconditionality' the developments ibid, pp. 122-125, discussing the text of J. DERRIDA on Plato's Socrate's Apology (appeared in J. Derrida and A. Dufourmantelle, Of Hospitality, Stanford, California, Stanford University Press, 2000).

${ }^{196}$ Ibid, p. 120. 
foundation. Of course, there must also be a 'threshold of acceptance' to signal the limits of tolerance or hospitality. ${ }^{197}$ Such limits are traced by French international public order ${ }^{198}$ and take the form of predetermined exceptions to the PIL ban on adoption. ${ }^{199}$ What is important is that, within these limits, the legislature has discretion in dealing with the foreign ${ }^{200}$ and in limiting the right to adopt.

${ }^{197}$ Ibid, p. 114

${ }^{198}$ Ibid, pp. 114 at n. 13, 117, 119, 133, 138, 144-145

${ }^{199}$ See supra at II.3. On the exception of article 370-3 (2) FCC (that the PIL ban on adoption does not apply if 'the minor was born and resides habitually in France') as 'clause d'ordre public' see P. HAMmJe, supra n. 74, p. 377 at n. 59 ; Id., supra n. 75 , p. 2950 , no 14.

${ }^{200}$ See supra at V.4 and V.5 on empirical and normative discretion, respectively. 